ADDRESSING THE NEEDS OF PEOPLE OVER THE AGE OF 65 IN GRUDZIADZ: A MODEL FOR LOCAL CARE SOLUTIONS

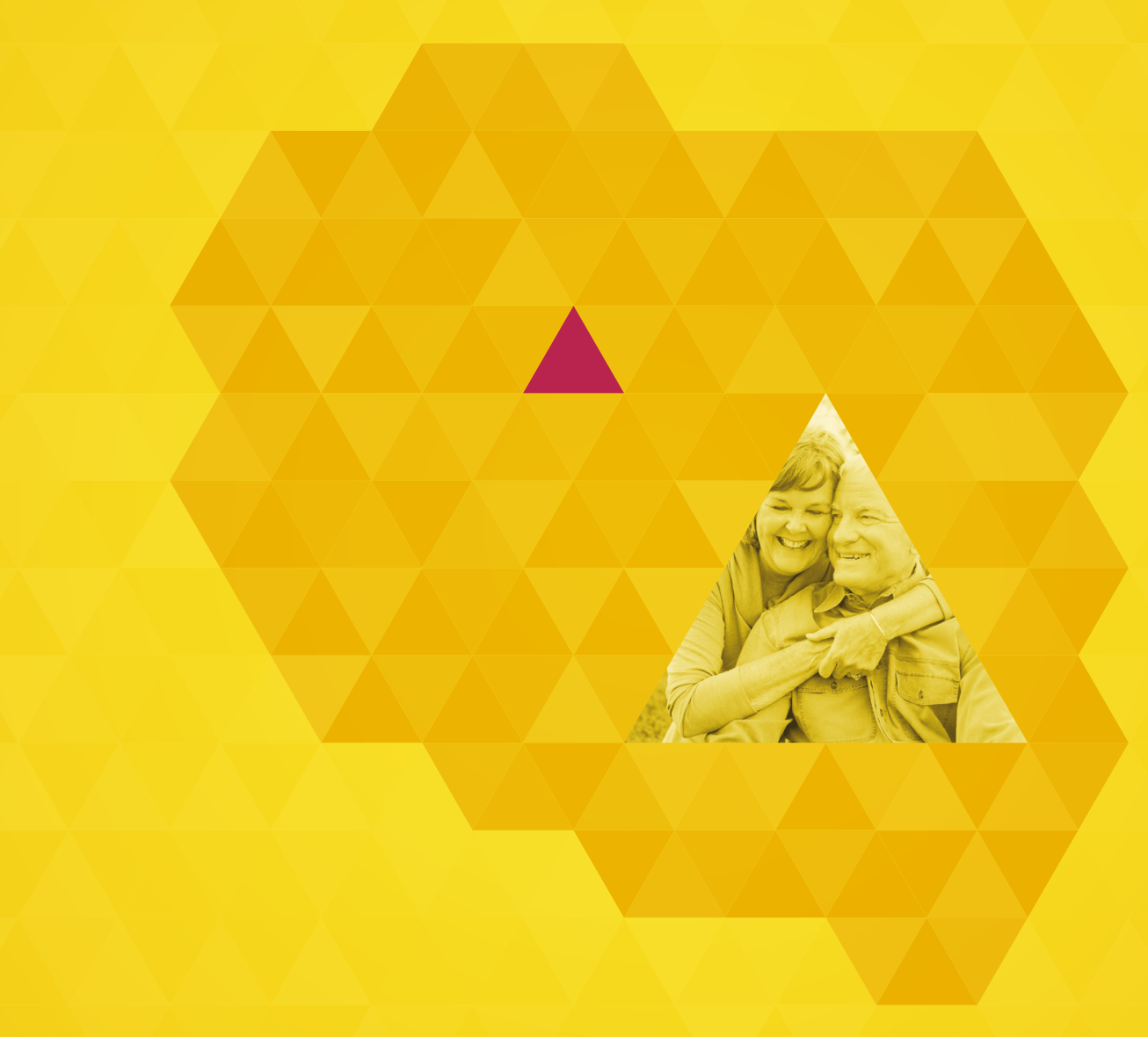

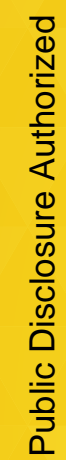




\section{POLAND RATCHING-UP}

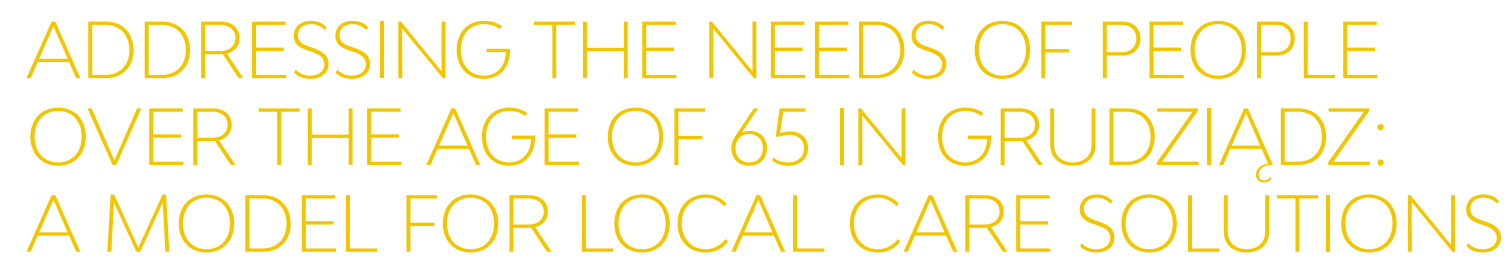


(C) 2019 International Bank for Reconstruction and Development / The World Bank

1818 H Street NW

Washington DC 20433

Telephone: 202-473-1000

Internet: www.worldbank.org

This work is a product of the staff of The World Bank with external contributions. The findings, interpretations, and conclusions expressed in this work do not necessarily reflect the views of The World Bank, its Board of Executive Directors, or the governments they represent.

The World Bank does not guarantee the accuracy of the data included in this work. The boundaries, colors, denominations, and other information shown on any map in this work do not imply any judgment on the part of The World Bank concerning the legal status of any territory or the endorsement or acceptance of such boundaries.

\section{Rights and Permissions}

The material in this work is subject to copyright. Because The World Bank encourages dissemination of its knowledge, this work may be reproduced, in whole or in part, for noncommercial purposes as long as full attribution to this work is given.

Any queries on rights and licenses, including subsidiary rights, should be addressed to World Bank Publications, The World Bank Group, 1818 H Street NW, Washington, DC 20433, USA; fax: 202-522-2625;

e-mail: pubrights@worldbank.org. 


\section{CONTENTS}

Acknowledgements

Acronyms

INTRODUCTION

DEMOGRAPHY T

$\begin{array}{ll}\text { Poland } & 10\end{array}$

Kujawsko-Pomorskie $\quad 12$

GRUDZIACDZ - SELECTED ASPECTS OF SERVICES FOR PEOPLE OVER THE AGE OF 65

Landscape 16

Use of services $\quad 17$

Analysis of the National Health Fund data, at the district and regional level,
for the year 2018

Analysis of the Social Assistance data, at the district and regional level, 2012-2018 20

Problems and priorities related to care needs $\quad 24$

IT architecture $\quad 26$

MODEL OF COORDINATED CARE FOR PEOPLE

OVER THE AGE OF 65

International approach examples 33

Proposed model of coordinated care for Grudziądz

$\begin{array}{ll}\text { Appendices } & 46\end{array}$

$\begin{array}{ll}\text { Notes } & 48\end{array}$ 


\section{TABLES}

TABLE 1 Population according to economic age groups in 1990-2017 in Poland, including people in the post-working age group

TABLE 2 Number of potential users of the new IT system designed for implementing the model of coordinated care for persons over the age of 65 ( ${ }^{*}$ with the inclusion of the common part - meaning the same patients and caregivers using health and social care)

TABLE 3 Recommended administrators and users of individual IT systems within coordinated care in Grudziądz

TABLE 4 Main IT-system elements

\section{FIGURES}

FIGURE 1 Poland's population by individual age groups (in percentages)

FIGURE 2 Projected population of post-working age in the Kujawsko-Pomorskie Region, for 2015-2050

FIGURE 3 Average number of visits to PHC facilities by patients

in the Grudziadz District and the city of Grudziądz, as well as

in the Kujawsko-Pomorskie Region, 2018

FIGURE 4 Share of patients using services at least once in 2018, by type of provider

FIGURE 5 Costs of services provided for patients over the age of 65 at various care levels in the Grudziądz District and the Kujawsko-Pomorskie Region in 2018

FIGURE 6 Average cost of care in PLN, depending on its level,

for a patient over the age of 65 in the Grudziądz District

and the Kujawsko-Pomorskie Region in 2018

FIGURE 7 Share of beneficiaries of social assistance in the general population in 2017 in the Kujawsko-Pomorskie Region, by districts

FIGURE 8 Number of persons who have been granted social assistance in the Grudziądz city municipality

FIGURE 9 Social assistance beneficiaries by age

FIGURE 10 Number of older people and share of the elderly among social assistance recipients

FIGURE 11 Number of people provided with care services, and the share of people over the age of 65 among beneficiaries of care services

FIGURE 12 Average cost of care service benefits per person receiving services

FIGURE 13 Average cost of one care service benefit

FIGURE 14. Average monthly cost of staying in a day-care home versus in a social assistance home per beneficiary

FIGURE 15 Structure of costs of staying in a nursing home shared between the beneficiary (client) and the municipality

FIGURE 16 The phase approach for the model implementation

FIGURE 17 Suggested process of coordinating care

FIGURE 18 Proposed by WB IT system architecture

FIGURE 19 Proposed by WB framework schedule for implementation of IT systems 


\section{ACKNOWLEDGEMENTS}

This report was prepared by a core team comprised of Anna Koziel, Anna Król-Jankowska, Agnieszka Sowa-Kofta, Tadeusz Jędrzejczyk, Artur Pruszko, and coordinated by Paul Kriss, Marcel Ionescu-Heroiu, Grzegorz Wolszczak, and Agnieszka Boratyńska. Peer review comments were received from Adrien Dozol and Ian Forde.

The team would like to thank Commissioner Corina Crețu for initiating the Initiative, Minister Jerzy Kwieciński from the Poland's Ministry of Investment and Economic Development for his invaluable support, and the European Commission's team for outstanding engagement and support, especially Marc Lemaitre, Erich Unterwurzaher, Christopher Todd, Wolfgang Munch, Justyna Podralska and Andrzej Urbanik.

The team would also like to thank Arup Banerji, David Sislen, Tania Dmytraczenko, Carlos Pinerua, Lars Sondergaard for the advice and guidance provided throughout the elaboration of this report.

The team is also indebted to all counterparts for the support offered in the elaboration of this study, the timely feedback, the excellent collaboration throughout, and their passion for developing their regions and institutions, especially:

from the Ministry of Investment and Economic Development: Aleksandra Sztetyłło-Budzewska and Anna Sulińska-Wójcik;

from the Marshal Office: Edyta Płaskonka-Pruszak, Marcin Heller, Joanna Gobinet;

from other stakeholders: from the Grudziądz City Hall: Szymon Jarosław Gurbin, Beata Przybylska, Ewa Niewiadomska-Roman; from the Social Assistance Home in Grudziądz: Aleksandra Kotewicz; from Military Specialist Outpatient Clinic: Anna Stańczak; from Medical Centre Jedynka Sp. z o.o.: Joanna Marcińska-Prytuła; from the Municipal Family Assistance Center in Grudziądz: Ilona Krysztyniak; from Dr. W. Biegański Regional Specialist Hospital: Elżbieta Kilian, Katarzyna Ziejka, Łukasz Przychodzki; from “The Breath of Hope” Foundation: Magdalena Pyszora-Załoga, Paulina Łącz. 


\title{
ACRONYMS
}

\author{
BDL Local Data Bank \\ CGA comprehensive geriatric assessment \\ CuR3 Catching-up Regions Three \\ DPS Day-Care Center \\ EU European Union \\ FGI focus group discussion \\ GUS The Central Statistical Office in Poland \\ IT information technology \\ LTC long term care \\ MO Marshal Office \\ MOPR Municipal Family Support Center \\ NGO non-governmental organization \\ NHF National Health Fund \\ OSC outpatient service care \\ PHC primary health care \\ ROPS Regional Center for Social Policy \\ $\mathrm{ZOL}$ care and treatment institution
}




\section{INTRODUCTION}

This proposed activity, under Catching-up Regions 3 (CuR3), is designed as a one-year engagement with three selected regions in Poland, based on their regional needs and priorities. The activities of this initiative build on the results of the CuR Initiative delivered by the World Bank and the European Commission over the last two years all across Poland.

The objective of this task is to propose a service delivery model that will facilitate care for the elderly over the age of 65 in Grudziądz. The European Union will support the implementation of the model by financing concrete care solutions, within the Eu's structural funds programs. The list of the possible solutions is presented in section 5.3 .

The purpose of this activity, therefore, was to work with the Grudziądz communities responsible for the provision of care and services for the elderly (representatives of the city office, Marshal Office (мо), regional hospital, primary health care facilities, and social care facilities) to help them rethink and reorganize elderly care. This effort includes care, services, investments, and new initiatives in a way that would strive to prevent the institutionalization of the elderly, as long as possible. This kind of undertaking provides opportunities for community and civic engagement to better coordinate and make use of various volunteer programs, local programs, and initiatives that will enhance people's individual skills and transform their attitudes.

The local system of care delivery for seniors does not stand alone, and should be molded with consideration to the broader context of policy and governance arrangements for health and social care already established in Poland, together with the funding, capacity, and systems that are currently in place. All local and national stakeholders from Ministries to non-governmental organizations or local community groups should be able to have a part in the model implementation. The proposed model builds on the national system's focus on the changes and adjustments that need to be made at the local level. This model takes into consideration already existing initiatives, such as EU-funded projects, as well as the constraints of the local conditions (like heavily indebted hospitals), in deciding how to move the elderly agenda forward.

The new service delivery model requires a new organizational setting, highly organized service delivery, different structures and clinical tools, skills, information flows, as well as additional financing for selected services and investments. Due to the natural limitations of this engagement, like timing, not all of the elements described above are included in the subject of this report. 


\section{DEMOGRAPHY}




\section{BOX1 Summary of demographic trends}

Poland is considered to be one of the faster ageing countries of the European Union. By 2050, the number of elderly people, i.e. aged 60 and over, will reach 13.7 million people - an increase of $51 \%$. In demographic trends, the Kujawsko-Pomorskie Voivodship is no exception - the national trends projected a significant increase in the number of residents of post-working age. Currently, $20 \%$ of people living in Grudziądz are over the age of 65 . Significant changes in the population structure are currently taking place as a result of vital statistics, migration and longer life expectancy. Population ageing is poised to become one of the most significant social transformations of the twenty-first century, with implications for nearly all sectors of society, including the demand for goods and services, such as health and social protection.

Poland is a country with one of the largest elderly populations in the European Union. However, this trend is not much different from the demographic trends predicted elsewhere in Europe ${ }^{1}$.

The Central Statistical Office in Poland (Główny Urząd Statystyczny - GUs) has demographic data for Poland up to end of the year 2017. ${ }^{2}$ Significant changes in the population structure are currently taking place as a result of vital statistics, migration and longer life expectancy. GUS indicates that this change can be clearly seen by the increase in the proportion of the post-working age population (women - aged 60 and over, men - aged 65 and over). In 200o-2016, this population increased by more than 2.1 million, up to 7.8 million people, and the share of the total population rose from $14.8 \%$ to $20.2 \%$. According to the preliminary data, at the close of 2017 the post-working age population was more than 8 million, and its share rose to nearly $21 \%$. In the case of this age group, the difference in the share of the population between the general urban and rural populations, is as high as almost $5 \%$. This is similar to other observations that indicate that the proportion of the population that is in this age group is growing faster in the smaller local communities.

In recent years, the number of people over the age of 80 rose twofold. In the year 2000, the number of people in the oldest age category totaled 774,00o, and in 2016, it was already more than 1.6 million, accounting for $4.2 \%$ of the total population of Poland (see Table 1 ). 
TABLE 1 Population according to economic age groups in 1990-2017 in Poland, including people in the post-working age group

\begin{tabular}{|c|c|c|c|c|c|}
\hline Age groups & 1990 & 2000 & 2010 & 2016 & 2017 \\
\hline Total populati & \multicolumn{5}{|c|}{$100 \%$} \\
\hline \multicolumn{6}{|l|}{ Aged: } \\
\hline $\begin{array}{l}\text { Pre-working } \\
\text { (0-17 years) }\end{array}$ & 29.0 & 24.4 & 18.8 & 17.9 & 18.0 \\
\hline $\begin{array}{l}\text { Working } \\
(18-59 / 64)\end{array}$ & 58.2 & 60.8 & 64.4 & 61.9 & 61.2 \\
\hline Mobile (18-44) & 40.1 & 39.8 & 40.0 & 39.1 & 38.7 \\
\hline $\begin{array}{l}\text { Immobile } \\
(45-59 / 64)\end{array}$ & 18.1 & 21.0 & 24.4 & 22.8 & 22.5 \\
\hline $\begin{array}{l}\text { Post-working } \\
\text { (60/65 years } \\
\text { and over) }\end{array}$ & 12.8 & 14.8 & 16.8 & 20.2 & 20.8 \\
\hline
\end{tabular}

Source: Poland's demographic situation as a challenge for social and economic policy

(Sytuacja demograficzna Polski jako wyzwanie dla polityki społecznej i gospodarczej), 2018.

Poland's population is expected to decline by 2.8 million according to the projections for the next 25 years, until 2040 (over the past 25 years it increased by more than 360,000 ). The greatest impact on this state of affairs will be exerted by mortality, that is, the baby-boom generation of the second half of the 1950s-currently around 60 or so-will start passing away. The predictions do not foresee an increase in births during this time.

By 2050, the number of elderly people (aged 6o years and over) will grow by 4.6 million (a 51.3\% increase), reaching 13.7 million. In 2016, the number of persons aged 80 and over was 1.6 million in Poland, of which $69.2 \%$ were women. In 2050, the number of people aged 80 and over will be more than twice as high -3.5 million, and the share of women of this age will decline to $63.6 \%$ (see Figure 1).

FIGURE 1 Poland's population by individual age groups (in percentages)

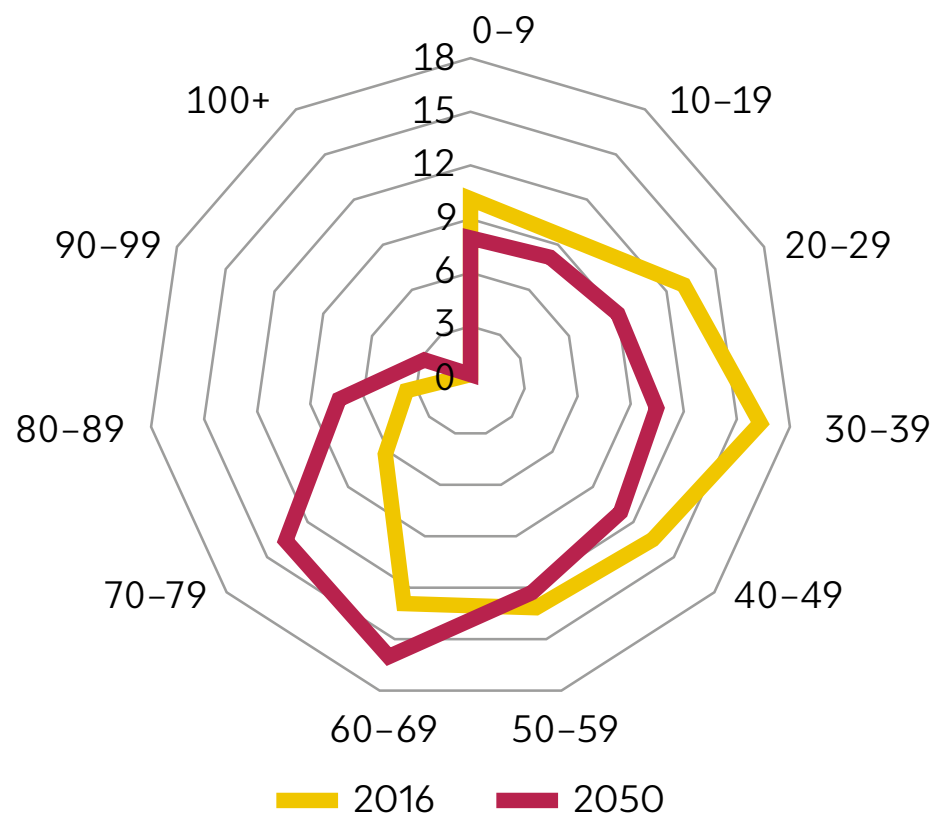


In terms of demographic trends, the Kujawsko-Pomorskie Region (Voivodship) is no exception. The trends projected by Gus point to a decline in the total number of residents of the region, with an increase in the number of residents of post-working age. ${ }^{4}$ (see Figure 2).

FIGURE 2 Projected population of post-working age in the Kujawsko-Pomorskie Region, for 2015-2050

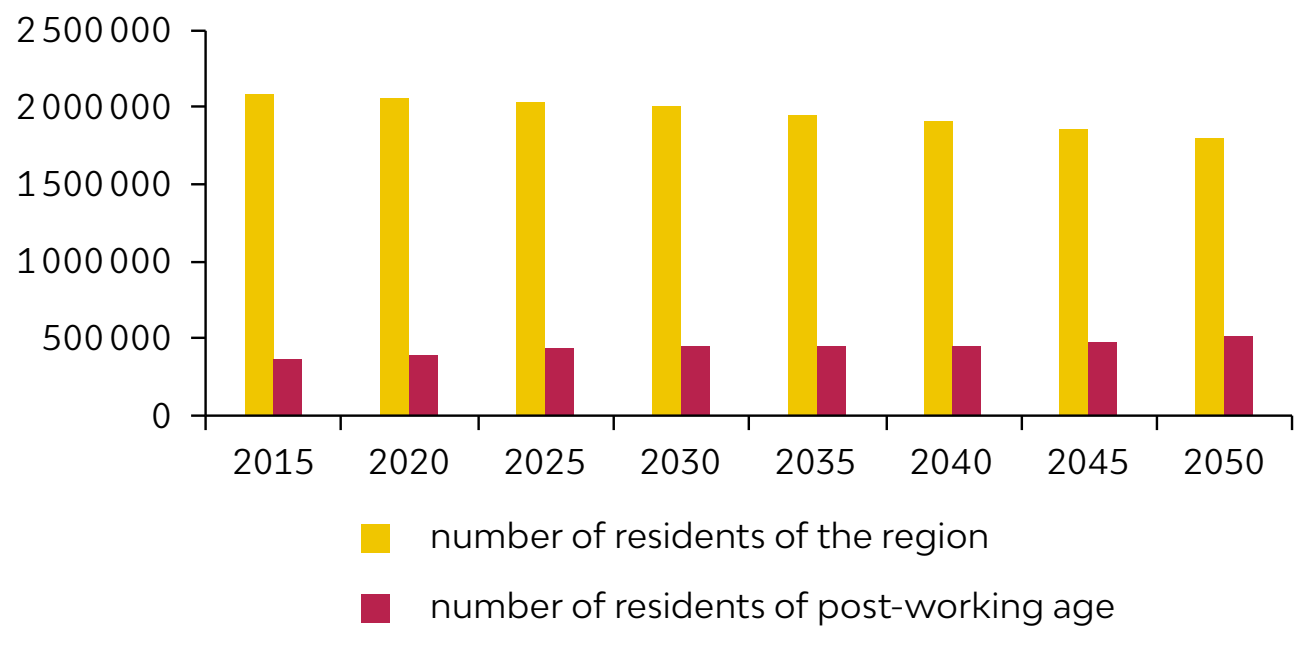

Source: GUS 2014

The demographic situation of the Kujawsko-Pomorskie Region places it close to the national average, but somewhat below the average aging of the population. The proportion of the population that has exceeded the age of 65 in the Kujawsko-Pomorskie Region rose from 9.9\% in 1990 (with the national average being a little over 10\%) to 15.3\% in 2015 (the national average being at $16 \%$ at that time). For 2040 , the projection is expected to reach $26.6 \%$ (and $26 \%$ respectively). ${ }^{5}$ 


\section{GRUDZIACZZ - SELECTED ASPECTS OF SERVICES FOR PEOPLE OVER THE AGE OF 65}




\section{LANDSCAPE}

\section{BOX 2 Summary of landscape}

Grudziądz has a well-developed system of social and health services, addressed to older people. We can distinguish following publicly funded care services available for elderly in Grudziądz: primary health care services, outpatient health care services, social care services, long-term care services, hospice and palliative care services.

Grudziądz is a city situated in Vistula Pomerania, in the Kujawsko-Pomorskie Region. Located on the picturesque right bank of the Vistula River, it serves as a natural eastern border of the Chełmno land, of which it is a part, both historically and geographically. The city has a population of 96,629 people (2017 data).

Publicly funded primary health care services in Grudziądz are provided by three types of institutions: Dr. W. Biegański Regional Specialist Hospital, Military Specialist Outpatient Clinic, as well as non-public health care institutions. ${ }^{6}$

Publicly funded outpatient health care services in Grudziądz are offered by four types of institutions: Dr. W. Biegański Regional Specialist Hospital, Military Specialist Outpatient Clinic, non-public health care institutions, as well as individual medical practices. ${ }^{7}$

Publicly funded social assistance services for the elderly are available at three institutions in Grudziądz: the Municipal Family Assistance Center (Miejski Ośrodek Pomocy Rodzinie MOPR), which is organized and located within a single entity; the Social Assistance Home (Dom Pomocy Społecznej - DPS), which has four different locations and provides services for a total of 412 beneficiaries, including those who are chronically, somatically and/or mentally ill; and the Day-Care Center (Dom Dziennego Pobytu) that is located in two separate places, one of which is in a social assistance home. ${ }^{9}$

The Grudziądz Roman Catholic Parish of St. Maximilian Kolbe has obtained financing and has launched the project Day-Care Center as a safe haven for dependent people from Grudziadz as part of the Regional Operational Program of the Kujawsko-Pomorskie Region for 2014-2020 (sub-measure 9.3.2, Development of Social Services). The project is addressed to people who are threatened by poverty or social exclusion, and the people who are part of their environment, particularly caregivers. The project offers support for people who reside in the city of Grudziądz. The purpose of the project is to improve the living conditions of 72 dependent individuals living in the city, by improving their access to quality care services provided in the local community, as well as improving the skills of 60 caregivers involved in caring for dependent individuals through August 31, 2019. ${ }^{8}$

The last two categories of publicly funded care available in Grudziądz are long-term care, and hospice and palliative care. Long-term care is offered in three places: Dr. W. Biegański Regional Specialist Hospital (long-term hospital care), Military Specialist Outpatient Clinic (long-term 
home care), as well as at Mps-Med Sp. z o.o. (long-term home care). Hospice and palliative care are also provided at the Dr. W. Biegański Regional Specialist Hospital (inpatient hospice and palliative care) and at Mps-Med Sp z o.o. (hospice and palliative care at home).

Altogether, there are approximately 500 publicly funded 24-hour beds for the elderly in need of such care in Grudziądz (hospital: palliative care unit-16 beds; long-term palliative care -68 beds, social assistance home-412 beds $\mathrm{s}^{10}$ ). In 2018 , long-term care was provided for 124 people over the age of 65, while care-treatment establishments (zakłady opiekuńczo-lecznicze - zOL) provided services for 174 persons over the age of $65 \cdot{ }^{11}$

\section{USE OF SERVICES}

A quantitative analysis of availability and use of health and social services was carried out using data obtained from the National Health Fund and Social Assistance. Because health data were provided to the World Bank only for the period of one year (2018), the possibility of a proper assessment of the health situation of elderly residents was therefore very limited. In turn, data from the field of social services were made available to us for the years 2012-2018, and consequently it was possible to draw much more accurate conclusions.

\section{BOX 3 Summary of results based on health and social data analysis}

Grudziądz has a sufficient number of health care workers who are covering the needs of elderly population. Compared with the rest of the voivodship, in Grudziądz there are fewer primary health care services carried out per patient. Specialist care, on the other hand, is used more often. As in the whole country, in Grudziądz the hospital care costs the most in total, including treatment of population $65+$. However, the highest costs per one patient $65+$ are within care treatment establishments. Moreover, patients $65+$ use health services more often than other age groups (including long-term care, specialist care, rehabilitation services).

From the perspective of social care we can conclude that elderly people are increasingly becoming assistance clients, mainly due to their care needs, provided for both in the home setting and institutionally. Due to the growing demand for services as well as their rising unit cost, social services for the older population are becoming an ever greater burden for the local social policy budget. The main problems accrue at the interface between the health care and social assistance sectors due to the lack of common and clear methods for evaluating the state of health and independence of an older person.

Based on the above, it was crucial to helped Grudziądz representatives rethink and organize care and services in a way that would prevent mentioned above problems as long as possible. It should be emphasized that the lack of integration between healthcare and social care services particularly affects older people.

\section{Analysis of the National Health Fund data, at the district and regional level, for the year 2018}

This analysis includes the patients who used health services covered by the National Health Fund (NHF) at least once during the calendar year of 2018. The data does not include information on services delivered by the private sector, whether paid out-of-pocket, or organized by the insurance companies and/or providers, based on employers' plans.

Altogether, in 2018 there were 1,887,711 insured individuals in the Kujawsko-Pomorskie Region, of whom 325,447 were over the age of 65 . In the case of the district of Grudziądz, in the city of Grudziądz, of the 121,904 insurees, 21,680 were seniors. Patients over the age of 65 represent almost $20 \%$ of the population of all patients, both in the region, as well as in Grudziądz. 
Primary health care (PHC) was used less often in Grudziądz by patients over the age of 65 than in the region

In Grudziądz, there were 19,827 patients over the age of 65 , who visited primary health care (25\% of all patients using PHC in Grudziądz, that is, individuals who actually visited a facility, and not only were declared as patients). The total number of patients who visited primary health care in 2018 in the Kujawsko-Pomorskie Region was 1,508,112, of whom 22\% were over the age of 65.

For each PHC patient over the age of 65 in Grudziądz, 6.1 received PHC care, while in the region, care was received by 8.6 (see Figure 3).

FIGURE 3 Average number of visits to PHC facilities by patients in the Grudziądz District and the city of Grudziądz, as well as in the Kujawsko-Pomorskie Region, 2018

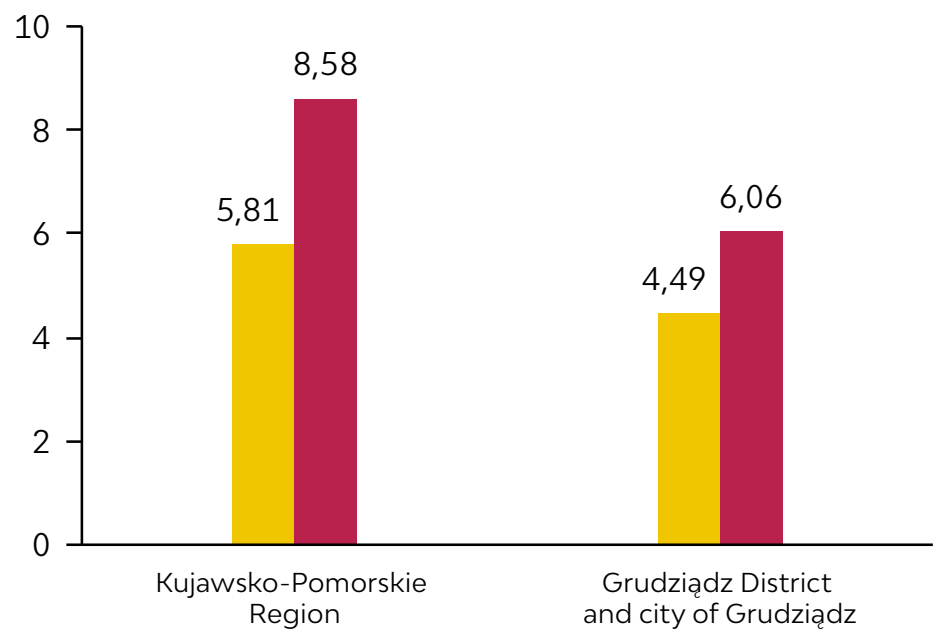

Average number of visits to PHC facilities, irrespective of age

Average number of visits to $\mathrm{PHC}$ facilities by people $65^{+}$

Source: own analysis based on NHF data

FIGURE 4 Share of patients using services at least once in 2018 , by type of provider

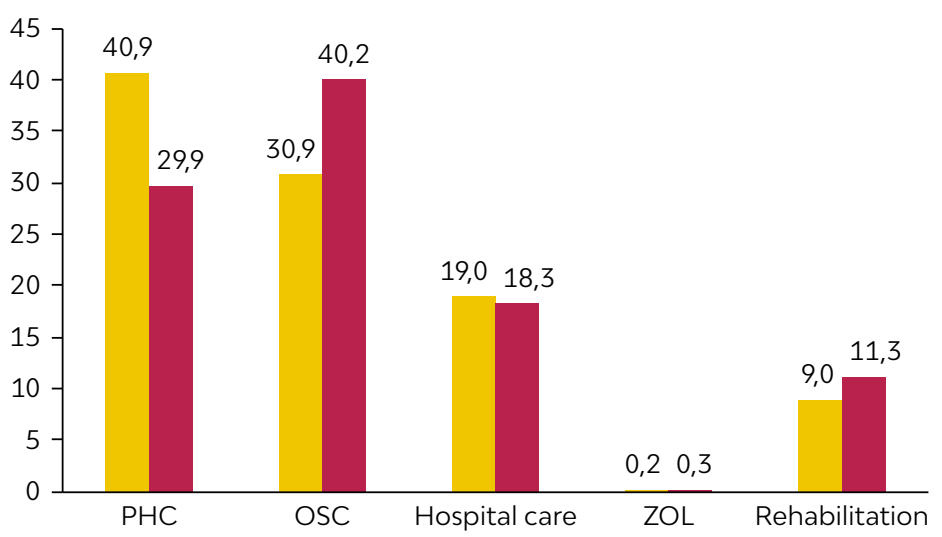

Kujawsko-Pomorskie Region

Grudziądz District and the city of Grudziądz
For every thousand patients in Grudziądz, there were, on average, 1.5 PHC doctors and 1.5 nurses (in 2018 one doctor received, on average, 667 patients; one nurse, 651 patients); in the Kujawsko-Pomorskie Region there were 1.14 doctors and 0.8 nurses, respectively. Altogether, in 2018, 1,723 doctors and 1,207 nurses provided primary health care in the Kujawsko-Pomorskie Region. In the Grudziądz District, health care was provided by 119 doctors and 122 nurses.

\section{Outpatient specialist care (OSC)} was used more often in the district of Grudziądz by patients over the age of 65 than in the region

In the Grudziądz District, patients over the age of 65 most often used outpatient specialist care (40.23\%), whereas in the Kujawsko-Pomorskie Region patients over the age of 65 most often used primary health care (40.89\%), as shown in Figure 4.

In 2018, the average cost of osc, per patient over the age of 65, was PLN 294 in the region and PLN 236 in Grudziądz. Patients over the age of 65 accounted for nearly $40 \%$ of all costs of outpatient specialist care. However, since the National Health Fund did not provide us with information about the number of osc visits granted in 2018, we could not calculate how many osc visits each patient over the age of 65 made.

In 2018, there were 1,440 specialist doctors admitting patients in the Kujawsko-Pomorskie Region, and 97 in Grudziądz. On average, for every thousand patients in the city, there were 0.93 specialist doctors; in the region, the average was 5.76-over six times more. 
In 2018, there was a total of 454,799 hospitalized patients (33.84\% were over the age of 65$)$ in the Kujawsko-Pomorskie Region, and 36,870 patients in Grudziądz (33.02\% were over the age of 65).

In 2018, the cost of hospitalization for patients over the age of 65 in Grudziądz was PLN 6,552, and at the regional level it was PLN 5,250. The total cost of the same services provided for patients over the age of 65 was PLN 79,788,195 in Grudziądz, and PLN 808,180,008 in the region (see Figure 5)

Rehabilitation services were used more often by patients over the age of 65 , both in Grudziądz, as well as in the region

Almost $40 \%$ of all rehabilitation patients in Grudziądz are over the age of 65 . Overall, in 2018 there were 206,195 patients in the Kujawsko-Pomorskie Region who received rehabilitation services (of whom $35.47 \%$ were over the age of 65 ), and 19,371 patients in Grudziądz (of whom $38.72 \%$ were over the age of 65$)$.

On the average, a single patient over the age of 65 in Grudziądz received 34 rehabilitation services. In the Kujawsko-Pomorskie Region the total per patient was 45 services.

In Grudziądz, the average cost of a rehabilitation treatment received by a patient over the age of 65 was PLN 657, while in the Kujawsko-Pomorskie Region, it was PLN 756. It is worth noting that approximately $45 \%$ of the total costs of rehabilitation services in the city and in the region concerned patients over the age of 65 .

\section{Long-term care (LTC) was used most often by patients over the age of 65 years}

Long-term care patients over the age of 65 account for less than $1 \%$ of all the insured patients of this age group. However, patients in this age group account for more than $80 \%$ of all the patients under long-term care treatment.

In 2018 in Grudziądz, the number of LTC patients over the age of 65 was 124 out of 140 in total. In the Kujawsko-Pomorskie Region, LTC was provided for 2,620 patients, of whom as many as 2,090 were over the age of 65 .

For each patient there were only o.44 long-term care nurses. In Grudziądz, there were a total of 62 LTC nurses. Although there were as many as 838 LTC nurses in the whole region, the difference in the proportions of access per patient to nurses was minimal.

Health care treatment facilities (ZOL) were used most often by people over the age of 65

Over $85 \%$ of the patients in health care treatment facilities are patients over the age of 65. In 2018, in the Kujawsko-Pomorskie Region a total of 2,171 patients received care in zOL, of whom 1,852 patients were over the age of $65(85,30 \%)$. In Grudziądz, the number of these patients was 201 and $174(86,57 \%)$, respectively. 
FIGURE 6 Average cost of care in PLN, depending on its level, for a patient over the age of 65 in the Grudziądz District and the Kujawsko-Pomorskie Region in 2018

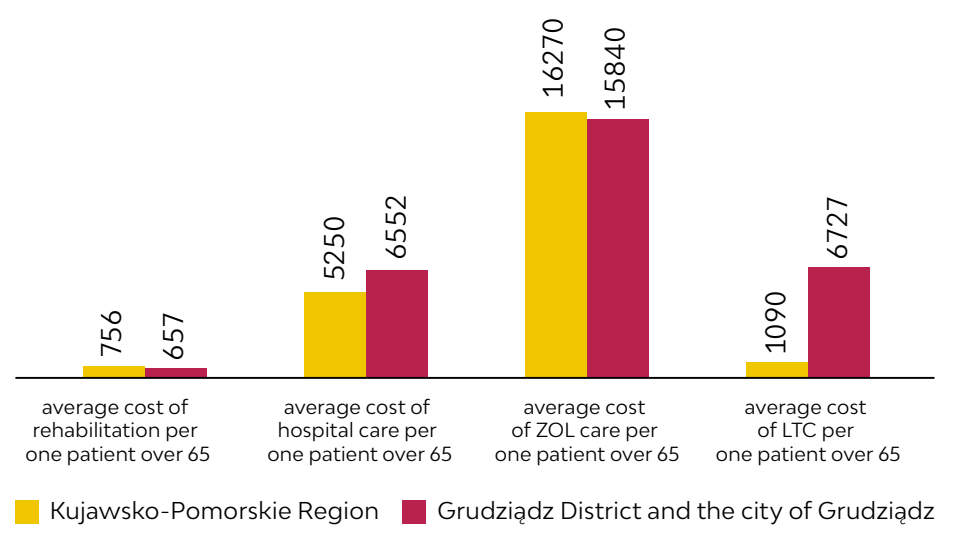

Source: own analysis based on NHF data.
The average cost of care within zoL per patient over the age of 65 was PLN 16,270 in the region, and PLN 15,840 in Grudziądz. The service in zOL is understood not as a single visit, but as the cost of the whole care package received within the facility over many days. The distribution of costs per patient over the age of 65 for different levels of care, is shown below (see Figure 6).

\section{Reimbursement of medications and medical devices}

The average annual cost of medication reimbursement per patient in Grudziądz was about PLN 853, and in the region about PLN 806. Expenditures on medications refunded for patients over the age of 65 totaled PLN 262,381,524 in the Kujawsko-Pomorskie Region, and PLN 18,511,682 in Grudziądz.

Patients over the age of 65 most frequently received co-financing for medical aids (this applies to $79 \%$ of patients in Grudziądz). In 2018, the amount of co-financing for medical equipment for patients over the age of 65 in the Kujawsko-Pomorskie Region was PLN 45,645,558, and in Grudziądz PLN 2,755,247.

The most frequently purchased item among patients over the age of 65 in Grudziądz was diapers. These were also the most frequently purchased article in the entire Kujawsko-Pomorskie Region for the above group of patients.

\section{Most frequent diagnoses and type of specialists visited}

The three most frequently reported diagnoses in hospital for the patients over the age of 65 in Grudziądz were: need further medical care, have retinal disorders, and have senile cataract. The region differs in this respect only regarding the third most frequently occurring disease, which was prostate cancer.

The three most frequently consulted specialists by patients over the age of 65 in Grudziądz were: ophthalmologists, general surgeons, and cardiologists. The three kinds of specialists seen most often by patients over the age of 65 in the region were, again, ophthalmologists, and then cardiologists, but the third most frequently visited specialist was orthopedists.

\section{Analysis of the Social Assistance data, at the district and regional level, 2012-2018}

The main task of social assistance is social work, based on providing services to those in need, mostly because of economic reasons, but also because of their dependence on others for daily living.

When viewed in relation to the Kujawsko-Pomorskie Region, Grudziądz fares relatively well, if we measure the poverty level by the number of people using social assistance. The share of beneficiaries of social assistance in the general population of Grudziądz in 2018 was lower than the average in the region, though slightly higher than in the biggest cities of the Kujawsko-Pomorskie Region-Torun and Bydgoszcz. At the same time, the share of long-term beneficiaries of social assistance among all beneficiaries was the lowest in the region (35.5\%), which may point to a relatively low durability of poverty. 
FIGURE 7 Share of beneficiaries of social assistance in the general population in 2017 in the Kujawsko-Pomorskie Region, by districts

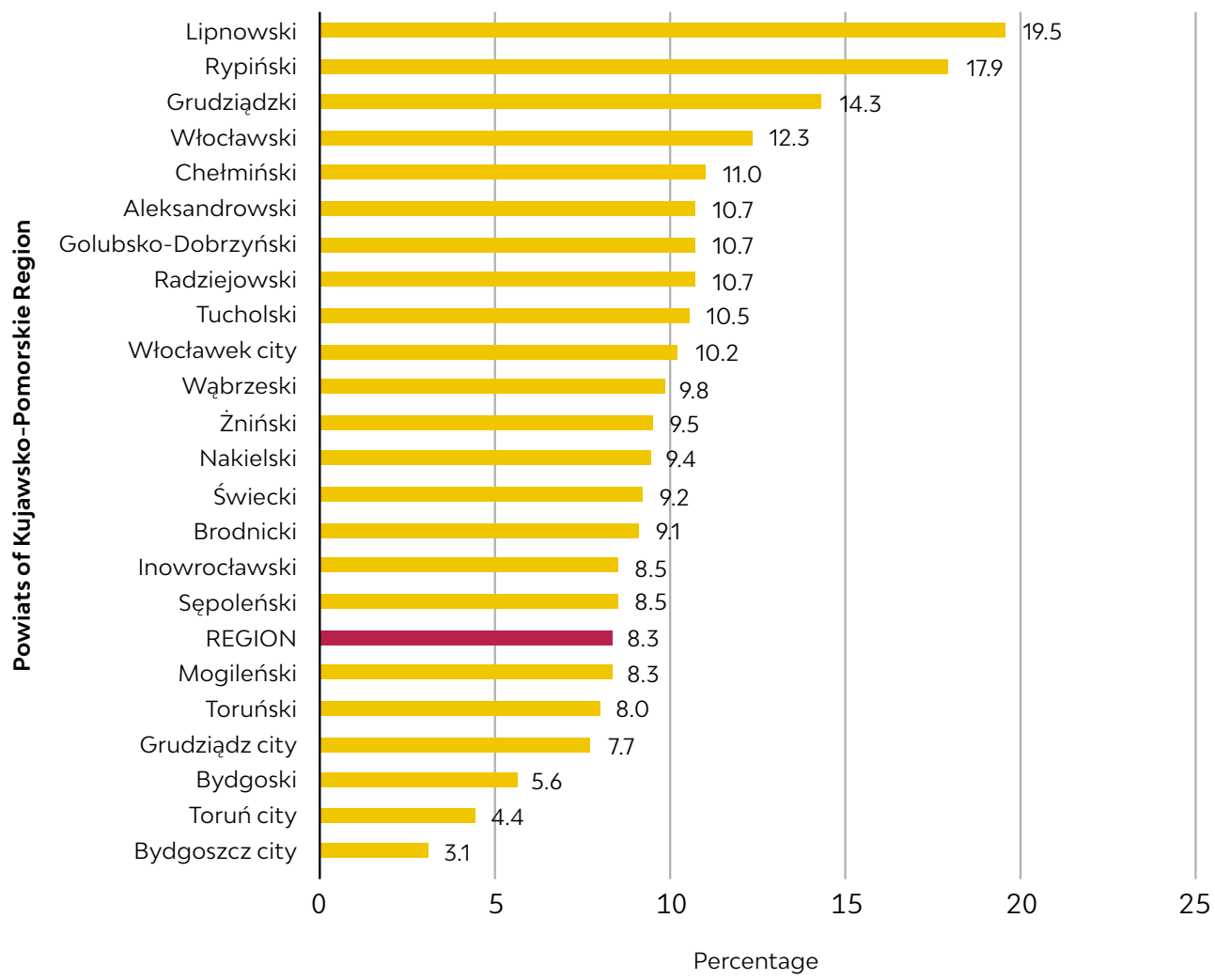

Source: assessment of social assistance resources, ROPS (Regional Center for Social Policy), 2018

The number of social assistance beneficiaries in Grudziądz is continually declining (meaning that the total number of users is decreasing, while the percentage of elderly beneficiaries is increasing), from 10,400 to 6,300 in 2018. This is concurrent with the national trends, and follows from the economic improvement and the drop in unemployment in the country, as well as in the region and at the local level.

FIGURE 8 Number of persons who have been granted social assistance in the Grudziądz city municipality

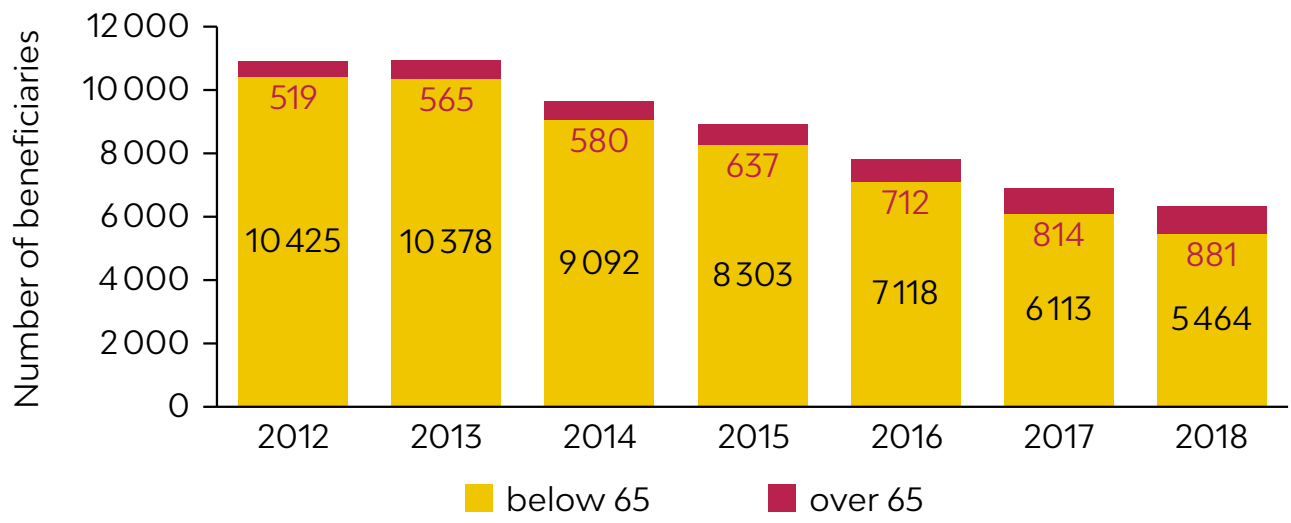

Source: own study based on MOPR (Municipal Family Assistance Center) data (2018).

However, more and more older people are becoming beneficiaries of social assistance. In 2012, seniors accounted for $4.7 \%$ of social assistance beneficiaries. In subsequent years, the number of older clients of social assistance rose nearly twofold, and with the declining general number of social assistance clients, in 2018 they accounted for $13.8 \%$ of all social assistance beneficiaries. 


\section{FIGURE 9 Social assistance beneficiaries by age}

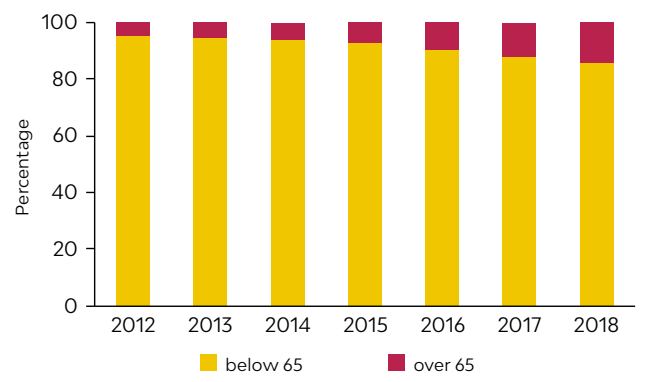

Source: own study based on MOPR (Municipal Family Assistance Center) data (2018).
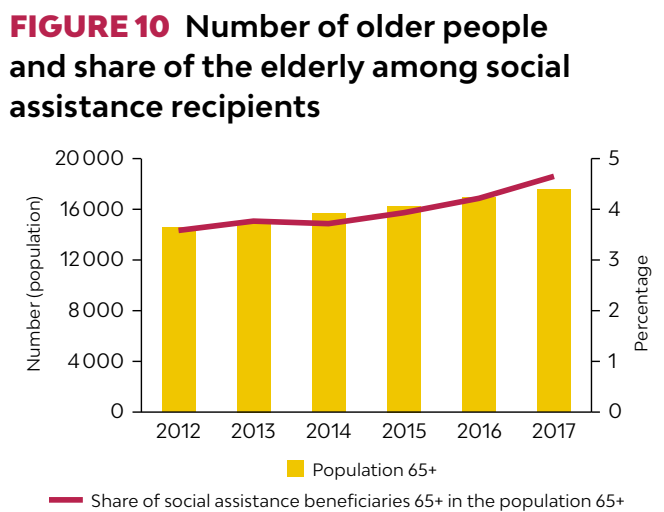

Source: GUS BDL (Central Statistical Office Local Data Bank) and MOPR data (2018)

In 2017, about $4.7 \%$ of people over the age of 65 received social assistance in Grudziądz. This means that with the growing number of older people in the population in recent years, the number of the elderly using social assistance has been steadily rising.

In Grudziądz, social assistance is provided in cash form more often than in-kind. In 2018, 83.2\% of the beneficiaries received cash benefits and 55\% benefits in-kind..$^{12}$ Older persons (over the age of 65) receive benefits in-kind more often, and the proportions between allocated cash and non-cash benefits in this group are the reverse of those among all social assistance clients. In 2018, $77.5 \%$ of older social assistance clients received benefits in-kind and $41.3 \%$ cash benefits. Studies

FIGURE 11 Number of people provided with care services, and the share of people over the age of 65 among

\section{beneficiaries of care services}

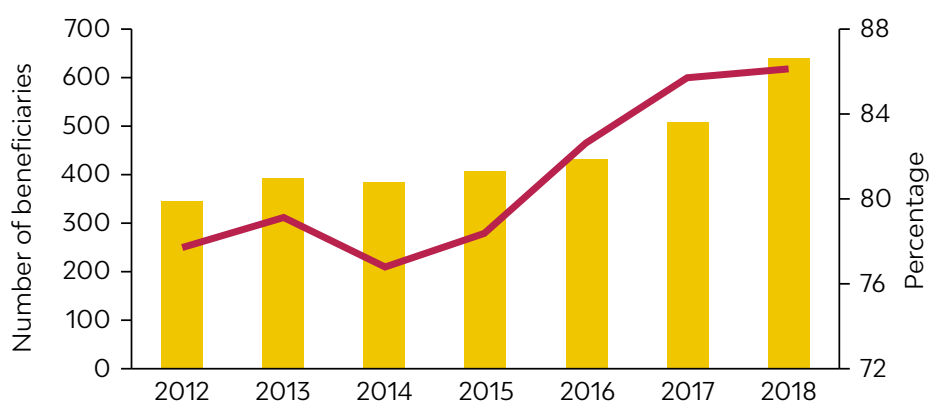

Number of people to whom care services were granted

Share of the elderly (65+) among those receiving care services

Source: own study based on MOPR data 2018 conducted in the Pomorskie Region show that benefits in-kind usually consist of meals, shelter and clothing, as well as care services.

Among the aged receiving social assistance in Grudziądz, $63 \%$ received care services. ${ }^{13}$ This is the most frequently allocated benefit to older people. In 2012-2018, the number of people who were allocated care services rose nearly twofold (from 345 to 640 ), and $86 \%$ of the beneficiaries of services in 2018 were elderly people.

Qualitative studies carried out among the older residents of Grudziądz show that the possibility of resorting to formal services of social assistance is being considered above all by singles without a family in Grudziądz or other close relations (neighbors, friends) who could provide care for them.

Older people, as well as professionals engaged in supporting the elderly, report that the lack of information is a barrier to care services. Often knowledge about the ways of obtaining support is described as 'secret' knowledge. The following issues are particularly problematic:

- Lack of knowledge about the support options

- Lack of transparency in the manner of awarding benefits/care

- The random nature of assistance-often assistance depends on whether the patient encounters a person who knows how the elderly care system works, what the possibilities of obtaining formal assistance are, and what the benefits are that he/she is eligible for

- Word of mouth-lack of education of the participants-in most cases they learn about possible help in an informal way from the staff of other institutions or friends

- Lack of formal communication paths between individual participants/institutions concerning the state of the patient/ward, the continuation of care for the older person, as well as no feedback 
Not only is the number of people receiving care services rising, but also the average cost of a benefit is getting higher. The average cost of a single care service for a person over the age of 65 is higher than that for the general beneficiaries of assistance. At the same time, the average monthly cost of care for an older person is lower than the average cost of care services, regardless of age, which may indicate there is a lower intensity of care for the elderly. The increase in the cost of care might be related to the increase in wages (minimum wage and wage per hour on civil contract) observed in the last years.

\section{FIGURE 12 Average cost of care service benefits per person receiving services}

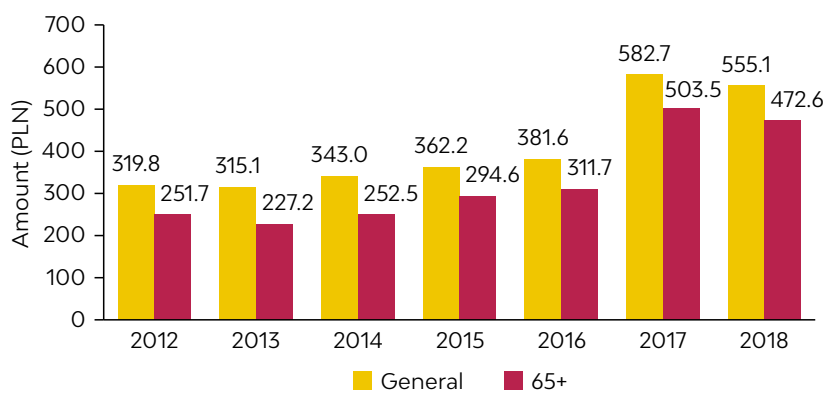

Source: own study based on MOPR data 2018

\section{FIGURE 13 Average cost of one care service benefit}

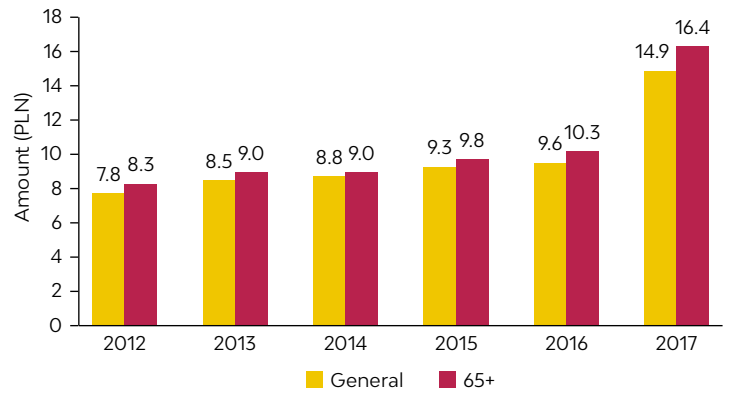

Source: own study based on MOPR data 2018.

The elderly in Grudziądz also use the services provided in a daycare home and 24-hour care in a social assistance home (located in 4 places).

\section{In 2018, day care was provided for 123 persons, of whom $88.6 \%$ consisted of persons over the age} of 65. In previous years, seniors accounted for $100 \%$ of those who received such services, where the number of people receiving services ranges from about 110 to 120 people a year.

In 2018, there were 472 people living in a social assistance home, of whom $48 \%$ consisted of people over the age of 65 . This is the largest group of users, distinguished by their age.

The average monthly cost of staying in a day-care home or in a social assistance home rose in 2012-2018, where in recent years the costs of institutional, 24-hour care especially rose.

The cost of a stay in a home is shared by the beneficiary, his family, and the municipality. Despite the general rise of the costs of staying in a social assistance home, for several years now the structure of costs has remained the same, and the beneficiary and his family cover about $26-28 \%$ of the total cost.

\section{FIGURE 14 Average monthly cost of staying in a day-care home versus in a social assistance home per beneficiary}

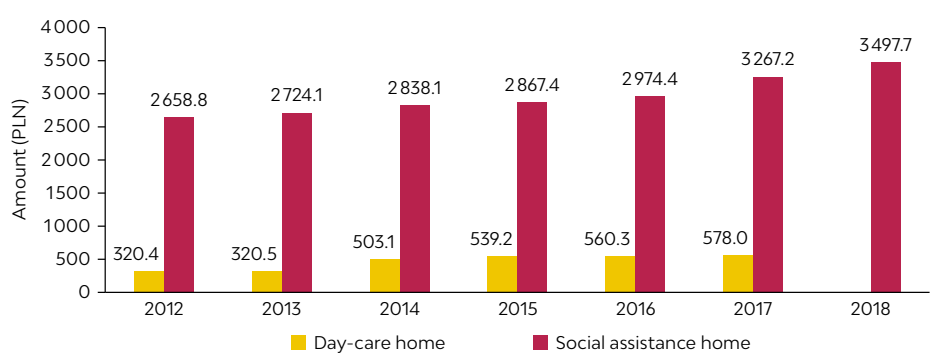

Source: own study based on MOPR data 2018.

FIGURE 15 Structure of costs of staying in a nursing home shared between the beneficiary (client) and the municipality

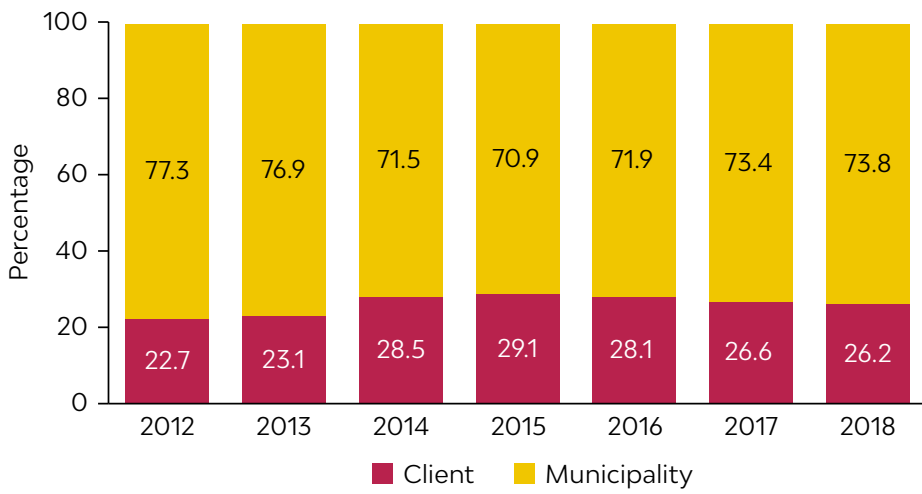


An assessment of the care needs of the elderly in Grudziądz was carried out at the beginning of 2019 using qualitative methods. A qualitative analysis was made on the basis of focus group interviews carried out in Grudziądz. This method consists of interviews in which a group of people were asked about their perceptions, opinions, beliefs, and attitudes towards a health and social services. Questions were asked in an interactive group setting where participants were free to talk with other group members.

\section{BOX 4 Summary of problems and priorities related to care needs}

The care needs most frequently pointed out by seniors were: insufficient information on own state of health; lack of health education on patient diseases, medications, health behaviors and risk factors; limited mobility in the case of living in multi-story buildings on higher floors without an elevator; lack or insufficient support of doctors in obtaining additional medical and care services provided by community nurses, caregivers, social assistance workers; no real involvement of personnel in the patient's affairs; the excessive medical bureaucracy in the case of a need for support from social assistance.

Based on the above opinions, the following actions are needed in Grudziądz: creating a set of information about support procedures available from each care institution in Grudziądz; education for senior persons aged $65+$ in scope of health - information/education on formal assistance system and possibilities of obtaining support from various institutions if such needs arise, as well as education of those, who would have contact with the senior persons and their caregivers; creating an information resource, which role would be to provide information to interested parties as to what kinds of assistance are available and from where.

Objective: In order to create a care model relevant to the local context, an assessment of the needs of the Grudziądz elderly was carried out at the beginning of 2019, using qualitative methods.

\section{Methodology}

A survey on the needs, the barriers, and the conditions of the system in which such care is provided was administered to participants of focus group interviews (FGIs). The topics covered by the survey were the care needs of the residents of Grudziądz, as well as the health and social care available within the city. A detailed description of the survey can be found in Appendix 1 .

A qualitative analysis was made on the basis of the focus group interviews carried out in Grudziądz. Altogether, six FGIs were carried out. Three of these concerned health/social care employees, that is, doctors, nurses, social assistance caregivers, and physiotherapists. Another three FGIs concerned individuals aged 65-74, seniors over the age of 75, and family caregivers. These interviews took place in March 2019. A total of 41 people took part in the study. ${ }^{14}$

\section{Results: Health care}

The findings highlighted the positive, optimistic picture that patients have of their state of health, the self-care possibilities, and their own well-being. These findings should be approached with caution for one main reason-participation in the survey was voluntary. A person in a negative state of mind, or with mobility problems, would be more likely to refuse to take part in the survey, thereby biasing the results of the survey. ${ }^{15}$

The respondents pointed out the poor involvement of doctors, nurses and physiotherapists in helping them solve problems regarding the continuation of care, or in consultations about the use of options other than health care that might improve their state of health. The feedback on their own state of health very often turned out to be inadequate. When a health problem was not accurately defined, the patient was not treated in connection with the established diagnosis, and felt symptoms that lowered the quality of his or her life. Whereas, the first declarations of the respondents on their state of health were generally positive, further questions 
led the participants to a more open description of their own health problems and the resulting functional limitations. Another obstacle to the development of quality health care services was the patient's lack of education.

The health care issues most frequently pointed out by seniors were:

a. Lack of information on their own state of health, that is, a poor connection between the symptoms felt or observed by the patient and the established diagnosis he/she received, or at times, the absence of a concrete diagnosis at all

b. Lack of health education adequate to the disease or diseases of the patient, no or little knowledge about medication, health behavior, and risk factors

c. Lack of mobility in the case of seniors living in multistory buildings on higher floors without an elevator

d. Lack of the support from the doctors in obtaining additional medical and care services provided by community nurses, caregivers, and social assistance workers

e. Lack of a real involvement of personnel in the patient's affairs

f. Excess of medical bureaucracy in the case of a need for support from social assistance

Respondents demonstrated an openness to new solutions, and a readiness to take part in additional training and workshops in this field.

Excessive bureaucracy was one of the main problems raised by the medical personnel in the survey. The actual burden of this problem should be verified, evaluated, and taken into consideration through observational studies. This administrative burden should also be taken into account when creating the information technology (IT) infrastructure to support care management. It should be noted that the many legal limitations, the relations between individual entities, the formal requirements of various services, regulations on the protection of personal data and patient rights, all require considerable attention in the eyes of medical professionals in designing new solutions for coordinated care for Grudziądz.

\section{Results: Social assistance}

Among the respondents in the group interviews, there were no beneficiaries of social assistance present. Despite the significant increase in the number of the elderly receiving social assistance, they could not be drawn to take part in the survey. Other respondents pointed out the absence of information about care services from social assistance. At the same time, the specialists stressed the need for the formal coordination of activities, taking into consideration the transfer of information on patients/wards in need of assistance, and the education of patients about the possibilities of obtaining services from the individual institutions.

Information on the possibilities of obtaining care for a dependent person is hard to come by, according to the social workers, caregivers and other social assistance workers. This applies to the institutions in the health care system, as well as the social assistance service itself. According to the respondents, information about the possibility of obtaining assistance should, in particular, be provided to hospitalized individuals whose caregiving needs may be considerable following hospitalization, and then upon returning home. Usually, however, such information is not given to the patients, and the lack of formal communication paths between the participants in the process of treatment and care of a patient/ward results in considerable misinformation. In effect, only a small portion of potential clients obtain help. When describing the process of providing services, the social assistance caregivers pointed to the necessity of doing time-consuming household chores in the homes of the patients (for example, cleaning, cooking), that significantly limited the time for conversation, keeping company, or educating the patient. 
In the course of the interviews, a number of recommendations were put forward regarding the need for coordinated actions regarding the elderly, namely:

a) In education and access to information:

- Creation of a compendium of information on the procedures for supporting dependent elderly people in each institution of the system; two of the methods applied here could be a directory available at City Hall, and a helpline for patients/wards and their families

- Education of the individual participants of the system, in particular, the elderly and their families (caregivers) on the different ways to obtain formal care and support

b) In facilitating the use of health care, social assistance, and urban infrastructure:

- Develop the field of geriatric care, and conduct training for doctors in this specialty

- Provide urban transport to facilitate travel to medical institutions, combined with the possibility of 'door-to-door' transport for dependent elderly people

- Invest in housing and public infrastructure to facilitate the social integration of elderly people

c) In operating health care and social assistance:

- Reduce bureaucratic burdens (less reporting) in favor of medical help and care for an elderly person

- Separate the role of caregivers from assistance duties (such as, cleaning, shopping, and cooking), thereby allowing for the more effective use of time for actual patient care

- Make the professions of nurse and caregiver for the elderly more attractive (including financially)

\section{IT architecture}

As part of the assessment of the current IT status of the city of Grudziądz, the following analyzes have been carried out: analysis of IT systems of chosen medical entities; analysis of IT systems of chosen social assistance entities; analysis of the regional and national tele information platform projects.

\section{BOX 5 Summary of local IT architecture}

IT constraints identified in Grudziądz include: limited communication and information exchange between various entities involved in care, as well as the lack of plans for introducing such communication. Currently used IT systems do not allow tracking patient information between facilities. According to the national plans of the Ministry of Health and regional plans of Kujawsko-Pomorskie Voivodeship, in the next few years, selected medical data generated in medical facilities should be available to other authorized entities. However, the planned activities do not meet the information flow needs necessary to ensure adequate care information exchange.

The target infrastructure and IT software in Grudziądz should include elements such as: remote communication and management (telephone, e-mail, health status monitoring in a home environment); care plan and tools for managing a given case with remote communication based on health care and social facilities; electronic information and medical documentation for the sake of continuity of care and reporting systems. 
Coordination of care is largely a management activity that requires proper information support to be efficient and effective, both in the process of making decisions and in implementing them.

Information technology will be one of the pillars supporting the coordination of care for the elderly in Grudziądz. Ensuring individual benefit providers access to information about the patient in real time will help improve the patient's safety and the quality of services, while, at the same time, improving the continuity of care by facilitating coordination between the different institutions and forms of care.

IT infrastructure and software should include such elements as:

- Remote communication and management (telephone, e-mail, monitoring the parameters of the state of health in the home-care setting)

- Plan of care and tools for managing the given case with remote communication on the basis of the municipal care center and the PHC

- Electronic information and medical documentation to ensure the continuity and integration of the care/reporting systems

A potential area of additional advantages may be the so-called 'telemedicine'. A telemedicine program usually includes a centrally managed, client-adjusted set of services, such as: TeleTrauma, TeleRx, TeleStroke, TeleMental, TeleConsult and other interoperable ${ }^{16}$ solutions for exchanging information on the patient by entities operating in various procedures and at various levels of care.

Real-time knowledge about the services provided for the population over the age of 65 in Grudziądz can result in better treatment plans and improved quality of care for the patient. Information concerning individual plans for care, nursing, and rehabilitation should be in digital form and take into account:

- Information on the prescribed home visits, services, and so on

- Information on actually performed home visits and services, and others

- Type of medical, nursing and physiotherapy consultations

- Information on hospitalization

- Diseases

- Prescribed and administered medicines

- Cost of performed services

- Entities performing services

- Personnel performing actions related to care

Combined together, the data referred to above can form the basis for an electronic patient care card.

It is also worth considering the possibility of using new IT technologies as tools in preventionto monitor the health indicators of beneficiaries and to assess their health risks. This would involve IT tools used by patients in home settings, helping in daily life, and monitoring the patient's activity. An example of such a tool is watches that monitor blood pressure, sleep, falls and so on. Implementation of such tools would improve patient safety, and steer interventions towards circumstances in which they are necessary, and in the long run would also help lower the cost of treatment.

To assess the current IT status of the city of Grudziądz, analyses of the following elements were carried out:

- IT systems of medical entities (PHC/OsC, hospital)

- IT systems of social assistance entities: Regional Center for Social Policy (ROPS), Municipal

Family Assistance Center (MOPR), and social assistance homes

- Plans for the regional platform: "Building the Kujawsko-Pomorskie electronic medical documentation system"

- Platform P1 implemented by the Center of Health Information Systems 
The most important IT constraints identified in Grudziądz were:

- Limited communication and information exchange between the various entities expected to be involved in the future coordination of care

- Absence of plans related to the implementation of such communication

The basic information concept in the system of care coordination is an individual care plan that contains information on the performed, ongoing, and planned care measures of the given patient. The care plan may contain information on the patient's state of health, or contain references to such information that can be found in other information sources. Management of the care coordination system is aimed at the optimization of the use of available resources located within individual care plans, in order to ensure the best possible standard of care for patients.

The currently used it software does not allow for the full implementation of care plans, or even for the tracking of information about the patient between institutions. According to the national plans of the Ministry of Health and the self-government of the Kujawsko-Pomorskie Region, over the next few years medical data generated in medical entities will be made available to other eligible entities. Nevertheless, the planned measures do not meet the needs in information exchange necessary to ensure the proper coordination of care.

On the basis of conducted analyses, cases of the use of the following key application of IT systems in the coordination of care can be listed:

- Management of the coordinated care system (PHC, Office for Seniors)

- Implementation of care plan (PHC, other service providers, social assistance)

- Management of care paths (PHC)

- Engagement of patients and caregivers in the care process

The main groups of people who should be using IT are:

- Managing entities of the coordination process

- Entities implementing care plans (staff)

- Patients and their caregivers

In planning the IT system, the efficiency of its implementation and maintenance should be taken into account, including its effectiveness and costs, in relation to the number of performed tasks and the number of users. As for now, the following number of potential (active accounts) users has been estimated:

TABLE 2 Number of potential users of the new IT system designed for implementing the model of coordinated care for persons over the age of 65 ("with the inclusion of the common part - meaning the same patients and caregivers using health and social care)

\begin{tabular}{llll} 
Estimated numbers of users & Health care & Social care & Total \\
\hline Managing entities & $<100$ & $<100$ & $<200$ \\
\hline $\begin{array}{l}\text { Entities implementing } \\
\text { care processes }\end{array}$ & $<1,000$ & $<1,000$ & $<2,000$ \\
\hline Patients and their caregivers & $<45,000$ & $<15,000$ & $<* 50,000$ \\
\hline Total & $<46,100$ & $<16,100$ & $<* 52,200$ \\
\hline
\end{tabular}

Entities using IT systems that should be beneficiaries of the new information exchange system:

1. Entity responsible for the coordination system (Office for Seniors)

2. Health care entities, including:

a. PHC/osc clinics in Grudziądz

b. Regional hospital in Grudziądz

c. Rehabilitation 
3. Social care entities, including:

a. ROPs (Regional Center for Social Policy)

b. MOPR (Municipal Family Assistance Center)

c. DPS (social assistance home)

4. NGOS

5. Patients and caregivers 


\section{MODEL OF COORDINATED CAREFOR PEOPLE OVER THE AGE OF 65}


The main objective of the task was to propose a service delivery model that facilitates care for the elderly in Grudziądz. Based on obtained qualitative and quantitative data, extensive discussions with the local stakeholders and experts as well as the literature review on the available foreign care models for elderly, we proposed a model of coordinated care for the elderly in Grudziądz.

At the same time, numerous meetings were held with local stakeholders to discuss possible solutions for care for the elderly, which helped match the model to the city's real needs. In total, 5 meetings took place: the first meeting was aimed at familiarizing local stakeholders with the initiative of Catching-up Regions 3 and the plan to build within this initiative a model of coordinated care for elderly in Grudziądz. The second meeting was aimed at discussing the needs and problems of local stakeholders in broadly understood health and social care available in Grudziądz. The $3^{\text {rd }}$ meeting was aimed at presenting the health and social data obtained and analyzed by the World Bank. During the $4^{\text {th }}$ meeting, training was provided for the potential care coordinators in Grudziądz. This training was conducted by the representatives of PHC in Siedlce (Mazovian Voivodeship), where such care is already being carried out. During the last $5^{\text {th }}$ meeting, training in the field of overall geriatric evaluation was directed to a health and social care workers in Grudziądz.

As a target goal, coordination of care may have a leading role in planning and launching care for the aging population. Thanks to the cooperation of various institutions responsible at the local and voivodship level, within the legally supplied national tools, the local authorities may have an opportunity to improve the health and quality of elderly care within their area. International model examples indicate that in the first phase of implementation, the care programs may be implemented voluntarily in cooperation with independent partners (City Hall, PHC, social assistance homes). The next step, however, should consist of long-term agreements of a single organization in order to ensure a number of health and care services for elderly.

\section{BOX 6 Summary of model of coordinated care for people over the age of 65}

Proposed comprehensive model of coordinated care for persons above 65 in Grudziądz includes 4 main components.

Key model components:

1. Establishment of the Senior Citizens' Office - a unit dealing with planning, coordinating, monitoring and supporting data gathering, analytical work and implementation of project for the elderly people's in Grudziądz - i.e. within the City Hall

2. Establishing the function of an elderly care coordinator - i.e. within the primary health care facilities, in cooperation with other facilities providing local and regional care for elderly

3. Regular assessment of the health, well-being and independence status of elderly people, for the purpose of determining the scope and type of necessary care/assistance and provision of care plans accordingly to the assessed needs

4. Introduction of mechanisms of information transfer between health care and social assistance institutions about the state of health, needs and available services for elderly people

With the development of model, it is expected that after several years: Local entities and non-governmental organizations will be able to plan and implement services on the basis of an agreement setting out the framework of cooperation and coordination of human, material and financial resources; the Senior Citizen's Office will be creating structures to manage the needs of the elderly population in Grudziądz (including education of older people and their families, prevention programs, management of avoidable demand or public expectations); Information exchange systems (IT) will support providers of services in a vertically integrated way, connecting the social care with medical care. 


\section{INTERNATIONAL APPROACH EXAMPLES}

A list and description of the models of coordinated care for people over the age of 65 currently implemented and used in other countries is available in Appendix 2.

Based on the available literature ${ }^{17}$ one can essentially distinguish two types of models of integrated care for the elderly that could be inspiring for Grudziądz:

1. The community-based model, implemented locally, is based on cooperation between the different providers of care, focusing on home care, in which the coordination between health care and social care plays an important role.

2. The state/provincial model, implemented at the national or regional level, with a single administrative body and a common budget that ensures both health and social care, provided in the home and in the institutional setting.

The factors that distinguish the local model from those at the national or regional level, are: (a) focusing, above all, on the most important health and care needs of the elderly; (b) cooperation between different providers who jointly work for the continuity of care; (c) multidisciplinary care teams, which always include geriatricians; (d) an active role for the PHC doctors in the general management of the care for a patient; (e) inter-organizational coordination of home and community services, including access to institutional care; (f) financing various providers from already existing budgets; and (g) an integrated system of information and classification for home care.

As opposed to the above, the national models are more difficult to implement, since they usually call for changes in the existing legislation. Moreover, the implementation of such a model is a challenge for the organizations providing services, due to their joint financing. Nonetheless, such an approach also brings clear benefits. The features that essentially distinguish this model from the local model are: (a) a single administrative body, with legal powers for overall management of the health and social care; (b) a single common budget; (c) direct control over a wide range of available services, including home, community or institutional care services; (d) programs for the management of specific diseases, in which the cases of specific patients, if the need arises, can be brought for consultation to doctors of that particular specialization, (interdisciplinary teams per se are not usually employed); and (e) a system of classifying patients in accordance with their affiliation to a specific level of care.

As a target goal, coordination of care may take a leading role in planning and launching care for the population. Thanks to the cooperation of various institutions responsible at the local and regional level, the local authorities may have an opportunity to improve the health and quality of care in their area (within the framework of the legally supplied national tools). The providers of services include: hospitals, social assistance, local support, health or psychiatric care, and NGOs.

As the proposed model is innovative in its nature, a progressive approach could be taken in its implementation with broader involvement of NGOs and local community groups. The first step usually involves building the capacity and resources of local communities. This includes taking initiatives to change local policy, including elderly care and introducing integrated care. The participative, multi-stakeholder approach could lead to a different "demand" or "needs-led" way of looking at senioral policy and elderly care challenges, which connects the experience of users to the more specialized knowledge of different types of providers. Broader stakeholders involvement in the preparation phase and the service delivery going further then the "usual suspects" could generate new ideas and local solutions ${ }^{18}$. In recent years the term 'co-production' has been used to describe engaging community members and service users as equal partners in service design and delivery. This approach could be envisaged also in Grudziądz. 
The example of international models indicate that in the first phase of implementation, the care programs may be implemented voluntarily, in cooperation with independent partners (City Hall, PHC, social assistance homes, NGOs). However, the next step should consist of long-term agreements with a single organization, in order to ensure a number of health and care services.

\section{PROPOSED MODEL OF COORDINATED CARE FOR GRUDZIADZ}

The objective of the model is to address the lack of integration between the health care and social care services, which can particularly affect older people. We are dealing with coordinated care, when there are networks of providers of medical and care services in the market (clinics, hospitals, social assistance homes, and others) that are cooperating with each other, and where access to these networks is managed by coordinators for the overall care process. Better results are achieved through personal contact with a care coordinator and/or manager that is known by name, than through monitoring from a distance or through telephone support. It appears that effectiveness improves when the aim is to ensure the patient's well-being and independence in his/her daily functions, and to support the patient so that he/she can cope with their physical condition and lead a good quality of life, as opposed to an approach set on only reducing or treating the symptoms.

The stakeholders of such coordinated care should be: the patients, all PHC units in Grudziądz, the hospital in Grudziądz, the social assistance available in the area, the local NGos, specialist doctors cooperating with the above-mentioned PHC and hospital, physiotherapists, other providers of services for elderly people, and other local service providers (including caregivers), as well as the regional branch of the National Health Fund.

The comprehensive model of coordinated care for people over the age of 65 in Grudziądz should include the following components (elaboration below):

1. Establishment of the Senior Citizens' Office - a unit dealing with planning, coordinating, monitoring and supporting data gathering, analytical work and implementation of project for the elderly people's in Grudziądz - i.e. within the City Hall (Component A)

2. Establishing the function of an elderly care coordinator - i.e. within the primary health care facilities, in cooperation with other facilities providing local and regional care for elderly (Component B)

3. Regular assessment of the individual's health, well-being and independence status of elderly people, for the purpose of determining the scope and type of necessary care/ assistance and provision of care plans accordingly to the assessed needs (Component C)

4. Introduction of information transfer mechanisms between health care and social assistance institutions about the state of health, needs and available services for elderly people (Component D)

The model was proposed by us in the form of the ready-to-use Eu fische (see Appendix 3; the fische is available in Polish language version).

We have also proposed a number of potential projects (also in the form of ready-to-use eu fishes) that can support the implementation of individual stages of the model, and could be financed form the eu funds, such as:

1. Organization of training for health care and social assistance personnel, as well as families and informal caregivers in the field of: available tools for comprehensive assessment of the state of health and needs of a patient above 65, elderly care provision, 
care plans implementation, care givers competences, as well as database of potential volunteer workers (carers) willing to take care of elderly, etc. (see Appendix 4; the fische is available in Polish language version)

2. Building an IT tool enabling the creation of care plans for the elderly in Grudziądz, the so-called Care Plans (see Appendix 5; the fische is available in Polish language version)

3. Adjustment of current health and social infrastructure in Grudziądz, as well as city transport, to the needs and abilities of seniors (see Appendix 6; the fische is available in Polish language version)

Implementation of the model most likely will be conducted in phases. Not all of the proposed activities will have the same starting point. This usually happens, when the limited resources conditions (both financial and human) as well as institutions' capacity for implementation are present.

Elements of the model sustainability:

- Senioral policy - should be put as a core priority of the City Hall

- Dedicated city resources should be assigned as enabling condition for the senior policy implementation

- Any new projects implemented at the local level should consider and involve local community and stakeholders in the design and implementation phase

- Communication and communication channels between Grudziądz City Hall, local stakeholders and regional authorities could be used to enhance the policy implementation and minimize transaction costs (some development, such as IT regional system level could be also applied in Grudziądz)

The phase approach could also serve as a sustainability increase factor. Proposed components of the model implementation form the action plan, that if fulfilled systematically, will assure envisaged integration of services.

First step of the proposed model is establishing Senior Citizens' Office, for example in the Grudziądz City Hall. Having a unit there, with dedicated team, work plan, mandate and tools will assure the sustainability of upcoming EU projects.

\section{COMPONENT A}

Establishment of the Senior Citizens' Office a unit dealing with planning, coordinating, supervising and making decisions about the elderly people's care in the region - i.e. within the City Hall.

The establishment of the Senior Citizens' Office include: employment of personnel (at least two full time workers dedicated to delivering senior policy in Grudziądz), provision of equipment, as well as determination and assurance of operational costs.
FIGURE 16 The phase approach for the model implementation

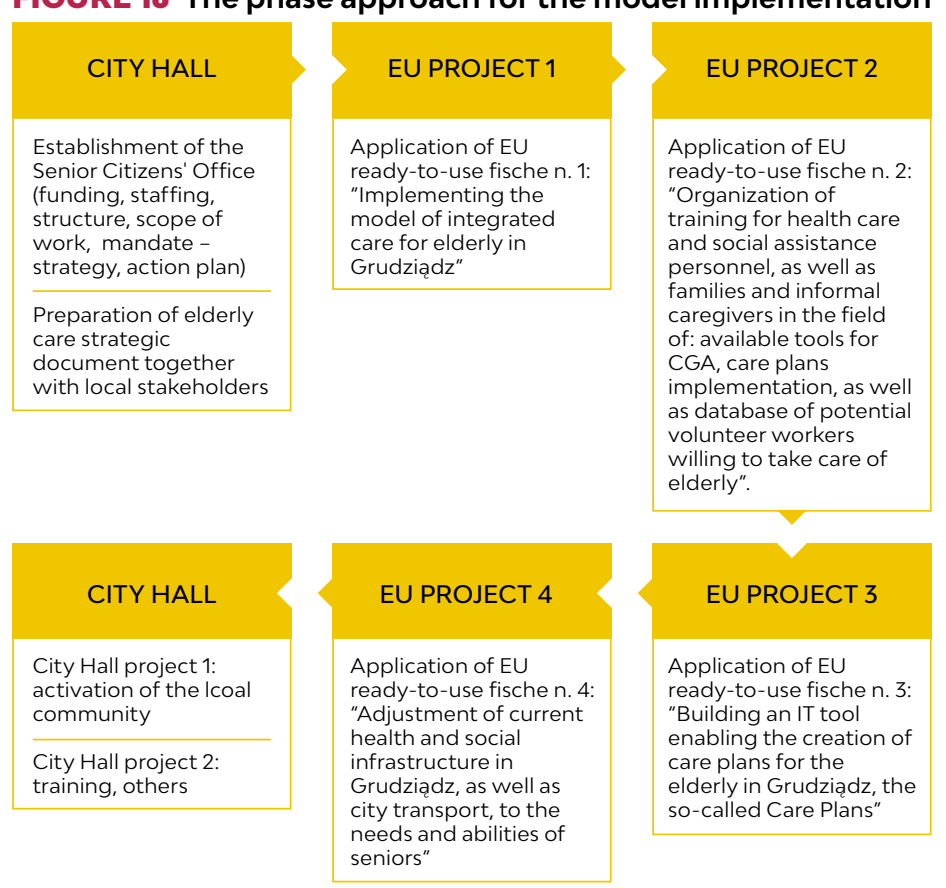


The main tasks of the office:

a. contacting point - information office for the population above 65

b. planning local activities related to the senior care, based on regular data collection and analysis in the area of elderly's care needs in Grudziądz

c. development of the EU and regional projects supporting implementation of the model

d. preparing care programs for seniors in Grudziądz, securing their implementation in accordance with an earlier established plan and timetable

e. monitoring of programs implementation in terms of quality and outcomes

f. improving communication between institutions, service providers, and supporting communications with patients

To build the relations needed for the efficient operation of coordinated care-time, social capital, and trust are needed. To ensure success, it is important to have effective communication and good relations between the people using the services, the staff of the health/social care, and the managers organizing the provision of services. A single optimal organizational model has not been chosen, nor a universal methodology for implementing coordinated care. However, as in many international experiences with implementing coordinated care, one of the main objectives is to promote such harmonized care outside of the hospital situation.

Envisaged budget for the component could be between 10 ooo and 20 ooo PLN per month depending on the final scope. Minimal annual funding that should be secured for the Senior Citizens' Office would therefore be in the rage of approximately 120 ooo PLN. Items on the component A could include:

- staffing costs (two full time staff in the City Hall office)

- computers with specialized IT software for data analyses

- additional funding for promotional and communications materials and tools to reach out the relevant stakeholders

Layout of a coordinated path for an older person through the health care and social assistance system (in accordance with their state of health and well-being):

1. Initial contact in the PHC, social care or hospital

2. Organization and planning —-individual care plans in the $\mathrm{PHC}$ - care planning by the team

3. Social assistance-consultation on the basis of a comprehensive geriatric assessment and an evaluation of the degree of independence-when needed

4. Implementation of the care plan by the PHC, or other entities, for example, a specialist, hospital, social care, community care, or NGOs

5. Verification once every two years of the care plan, based on the outcomes of the implementation of the care plan, and an assessment of the state of health and well-being of the patient 


\begin{tabular}{|c|c|c|c|c|}
\hline $\begin{array}{l}\text { MANAGING } \\
\text { POPULATION }\end{array}$ & DIAGNOSIS & CARE PLAN & CARE & EVALUATION \\
\hline \multirow{3}{*}{$\begin{array}{l}\text { Stratification of the } \\
\text { population, and on its } \\
\text { basis, the creation of } \\
\text { programs of support, } \\
\text { activation and care for } \\
\text { the elderly }\end{array}$} & \multirow{3}{*}{$\begin{array}{l}\text { Conducted by the } \\
\text { coordinator in the PHC } \\
\text { Support of health care } \\
\text { (HC) and social } \\
\text { assistance (SA) } \\
\text { professionals }\end{array}$} & \multirow{3}{*}{$\begin{array}{l}\text { Established by the } \\
\text { coordinator in the } \mathrm{PHC} \\
\text { With participation } \\
\text { (input) from HC, SC } \\
\text { and supporting } \\
\text { institutions }\end{array}$} & \multirow{4}{*}{$\begin{array}{l}\text { Organizations/institu- } \\
\text { tions dedicated to the } \\
\text { implementation of the } \\
\text { plan } \\
\text { Designation of care } \\
\text { plan implementation } \\
\text { milestones by the PHC } \\
\text { coordinator }\end{array}$} & $\begin{array}{l}\text { Conducted by the } \\
\text { coordinator in the } \mathrm{HC}\end{array}$ \\
\hline & & & & $\begin{array}{l}\text { Periodic checking of } \\
\text { plan implementation }\end{array}$ \\
\hline & & & & Fssential adiustments \\
\hline $\begin{array}{l}\text { Creation of regular } \\
\text { communication } \\
\text { between units }\end{array}$ & & & & $\begin{array}{l}\text { of the plan to } \\
\text { changing circumstan- } \\
\text { ces }\end{array}$ \\
\hline $\begin{array}{l}\text { Preparation of care } \\
\text { implementation tools } \\
\text { (IT, communication) }\end{array}$ & & & & \\
\hline
\end{tabular}

\section{COMPONENT B}

Establishing the function of an elderly care coordinator - i.e. within the primary health care facilities, in cooperation with other facilities providing local and regional care for elderly.

The institution providing the elderly care coordinator should have in its resources sufficient human and financial capabilities so it can properly supervise the process of including the patient in the coordinated care program, diagnosing the patients, managing patients' illness and monitoring patients' health. The elderly care coordinator should work closely with the regional authorities, which have an overview of local coordination projects and their funding possibilities, in particular from international sources.

It is possible to establish the following 2 types of coordinators:

Option 1: the coordinator is established within primary health care units (PHC); such a coordinator may be, for example, an employee of a health care system who is already working in the PHC facility (i.e. a nurse or a public health graduate).

Option 2: the coordinator is established as part of the local action group (Local Action Groups LAGs), which are often non-profit organizations involved in local activities for specific interest groups - in this case older people and dependent persons.

The coordinator is an independent entity, although he must work closely with local authorities, representatives of health and social care. His/hers activities could be financed mainly from the project resources, local community or National Health Fund. The number of coordinators depends on the size of the population covered. Minimum one coordinator should support population of 2000 patients above 65 .

The coordinator's tasks include:

a. Based on the health and well-being assessment, together with the health professionals, establishment of individual care plan for the selected group of patients

b. Agree on the care plan with the patient's family and teams involved in care plan implementation (also beyond the health facility)

c. Cooperation with $65^{+}$patients and their families (carers) in terms of access and type of health and social care available in the city - organizational support 
d. Cooperation with the Senior Citizens' Office as well as health and social care facilities (including care and treatment institutions, nursing homes, non-governmental organizations, etc.) in the scope of access and type of health and social care available to $65^{+}$ patients in the city

\section{Scope of coordinated services:}

- Primary health care services

- Home nursing services (checking the state of health, prescribed injections, help preparing prescribed medicines, changing dressings of wounds, and so on)

- Personal hygiene home services (for instance, washing routines)

- Services related to running households (help with chores, preparation or delivery of meals ['meals on wheels'], and other services)

- Specialist medical services (telemedicine/teleconsultations, rehabilitation, physiotherapy, and others)

- Dietetic consultations

- Support contacts with medical institutions (of first, second, and third degree)

- Managing chronic diseases

- Cooperation with local pharmacists to avoid polypharmacotherapy

\section{Medical services covered by the care plan:}

- Medical services

- Nursing services

- Basic general rehabilitation to mitigate the effects of impairment and improve the patients' mobility

- Psychological help

- Therapeutic activities

- Drug therapy

- Diet

- Assistance in obtaining medical and rehabilitation equipment needed for home care and rehabilitation

- Drug therapy

- Prevention of complications

- Consultations and medical visits in the clinics or in patients' homes, also for patients not eligible for home hospice care

- Health education to prepare patients, families, and caregivers for living and care in the home setting

However, it is important to note that most of the tasks listed above are part of the general practitioner's (GP) contract with the National Health Fund, though some of the medical services mentioned above are extensions of their competencies. Nonetheless, it is impossible to coordinate care and provide additional services without the approval and/or referral of the physicians in primary care.

\section{Providing services to an individual geriatric patient:}

- Assess the patient's state of health, based on a comprehensive geriatric assessment (CGA). The assessment should include health aspects, physical fitness, mental state, social support (including the family and financial situation), and the patient's standard of living - The PHC and a representative of the municipal social assistance center, should assess the patient's state, in agreement with specialist doctors (at least two), then draw up the care plan in coordination with the patient, his/her family members, and the team providing care

- The multidisciplinary medical team takes action in coordination with the PHC/community nurse, and in close cooperation with the PHC doctor 
- The care plan is financed mainly from the PHC budget. The municipal social assistance center ensures the in-kind contribution or support of the social workers, in accordance with the needs. If, after an assessment of the state of health has been done, the patient does not qualify for support from social assistance (according to the social worker), but such support is needed by him/her, co-payment for social services may be applied

- The care plan is updated at least every two years, according to need. The care plan is updated by a PHC/specialist designated by the PHC doctor, for example, a geriatrician, in accordance with the principles of the comprehensive geriatric assessment. The CGA serves as a platform for exchanging information on the geriatric patient within the team, with other service providers and social assistance. The CGA makes it possible to integrate services performed by a doctor, a nurse, a physiotherapist, a psychologist, and a social worker with the social assistance services

- The PHC team works in the form of medical councils devoted to a specific case (including virtual councils), in order to monitor the state of the patient, and adjust his or her medical and community interventions, and rehabilitation, as needed

- The team is also engaged in promoting health education and the prevention of disease/ disability, among the elderly and their families or caregivers

Depending on the final scope of the activities for the coordinators as well as potential additional health and social services to be included in the package of the care plan, a budget could be estimated.

\section{COMPONENT C}

Regular assessment of the individual's health, well-being and independence status of elderly people, for the purpose of determining the scope and type of necessary care or assistance.

An assessment of the patient's well-being is not limited to the identification of the disease(s) he or she is suffering from, or the symptoms that lower the quality of the daily life. Other elements of key significance are the assessment of bodily functions, mental well-being, and social relations. The assessment of the patient's bodily functions is crucial in an intervention to support a patient whose daily life has been hampered due to a loss of individual functions.

Apart from selecting and developing a tool for assessing the well-being of the wards within the coordinated care, it is also important to properly use data, and to verify the correctness of the data collection process.

The most advanced and comprehensive way to regularly assess the health and well-being of the senior is the Comprehensive Geriatric Assessment (CGA). This tool is so extensive that it is considered to be an interdisciplinary process of assessing the state of physical and mental health, behavioral activities, including intellectual potential, functioning in a social environment, as well as defining the social and health needs of an elderly person.

CGA will be carried out by a pre-established elderly care coordinator in cooperation with a doctor, nurse, physiotherapist and social worker. It should be carried out when the seniors enter the coordinated care project, and then it should be repeated periodically whenever necessary.

\section{Comprehensive Geriatric Assessment (CGA) ${ }^{19}$}

This tool should be recognized as an extensive interdisciplinary process of assessment of the state of the individual's physical and mental health, his/her ability to function on all levels, including intellectual capacity and performance in social circumstances, as well as a broad identification of the patient's physical health, mental and social needs. The process should be carried out by a team composed of a doctor, a nurse, an occupational therapist/physiotherapist and a social worker. Thus, the CGA is not a one-time tool, but rather a set of standardized interviews, which 
when carried out, form the basis for an extensive health program. At the same time, each of the diagnosed areas can be carried out autonomously and may provide a basis for interventions of a limited scope. A CGA is designed to determine the capacity of an elderly person to function independently in his/her surroundings and to determine their health and care needs. For an assessment of the state of health, it is particularly significant to have modules that explicitly allow for an assessment of physical functioning (ADL) and functioning in the home environment (IADL), as well as the mental state, including the risk of depression.

Additionally, the CGA can be supplement with social circumstances assessment.

\section{Social circumstances assessment}

An assessment of the social circumstances, carried out by a social worker, should be based on a community interview applied in social assistance centers, expanded to include the following questions:

- Is the person living alone? If not, then with whom (spouse, siblings, children, grandchildren)?

- Does the person maintain regular family contacts? If so, then how often (1-4 times/week, every day)?

- Are these contacts in the form of visits (direct contact)? (yes/no)

- Are there people in the closest surroundings (family, neighbors) who can provide direct and regular support in running the house or care support?

- Is the person currently obtaining support and, if so, then from whom (family, friends, neighbors, privately paid caregiver, other-specify)?

An assessment of the state of health and social functioning should make it possible to outline a plan for assistance and care services, and to set out a comprehensive care plan. In the case of services, the following needs should be taken into consideration:

- Preparing meals and cooking

- Assistance in eating

- Going to bed, getting out of bed, sitting down and standing up from a chair

- Dressing and undressing

- Using the toilet (WC)

- Washing the whole body, bathing

- Cleaning the house

- Going out for walks

- Doing the shopping

- Use of other household appliances: washing machine, television, and others

- Taking medication

- Medical actions: measuring blood pressure, giving injections, measuring the insulin level, changing dressing

- Contact with bank and public offices

- Contact with health care establishments (registration with a doctor)

- Using special devices assisting in moving around (walker, wheelchair, cane, crutches)

- Using telecare, telemedicine (for example, an emergency button)-remote-control devices that inform about the state of health, and facilitate intervention in the case of a life-threatening situation

Envisaged budget for the component C could be between 200 and 300 PLN per persons above 65 living in Grudziądz and using PHC services. Minimal annual funding that should be secured for screening 21 ooo seniors in Grudziądz would therefore be 4200 ooo PLN if all seniors would be participating in the CGA. Items on the component $C$ budget could include:

- Coordinators time (communicating with the population, inviting citizens for the CGA),

- Nurse time - conducting the CGA

- PHC and geriatric doctors - conformation of assessment

- Additional communication and CGA tools (questionaries' printing for example) 
The set of materials helpful in the assessment of the health status of patients above 65 years, including the questionnaire of the Comprehensive Geriatric Assessment, was attached to this report (see Appendix 7; materials are available in Polish language version).

\section{COMPONENT D}

Introduction of information transfer mechanisms between health care and social assistance institutions about the state of health, needs and available services for elderly people.

\section{Tools supporting the implementation of coordinated care in Grudziądz:}

There is a need to create a set of tools that will help implement coordinated care in Grudziądz. The level of advancement of the tools may vary-from IT and management tools, to newly created tools concerning systems for enforcing rules and control, gathering data, and monitoring and evaluating actions.

The following will be necessary:

- Improvement of the knowledge and basic efficiency of the service providers, hiring additional workers for care and social assistance, and ensuring new and modernized medical equipment to support the performance of care, with the exclusion of investments in infrastructure and advanced equipment

- Brief refresher courses to train medical personnel in topics related to diagnostics and the implementation of newly introduced expanded actions (for example CGA, as well as practical on-the-job training, for instance, in communication or health education). Particular attention should be focused on issues related to the transfer from the current care model based on corrective medicine, to the preventive care and education model

- Substantive support and training of personnel in topics concerning the implementation of coordinated care (for example, managing contracts, monitoring and reporting requirements)

- Modernization and expansion of the system of information on health, and the training of personnel in the use of such software, in particular, IT systems compatible with the systems used in social assistance (such as Emp@tia)

- Tools for anticipating risk (an undesirable event, such as hospitalization) if used alone, will have no impact on the health outcomes in the population. For there to be a real impact (resulting from risk assessment), additional interventions by the care team, as well as behavioral changes on the part of the patient, are needed. The population may be divided into different groups on the basis of the following:

- Risk stratification

- Age and state of health

- Social and demographic circumstances

- Behavior

Stratification of a given population may be carried out, both at the PHC level, and at the level of City Hall, or the regional branch of the NHF. 
For the population over the age of $65 \mathrm{in}$ Grudziądz, the division of patients into groups according to the services received, should be based on the health risk assessment regarding:

- State of health (CGA)

- Rehabilitation needs

- Nursing care needs, assistance in taking medication and using medical equipment

(an assessment of the state of health and care needs should be carried out in the hospital)

- Level of functional impairment (geriatric assessment, on the Barthel scale)

- Personal care needs

\section{Proposed IT solution}

The planned IT solution should have a modular architecture, based on open standards, to permit the expansion of the system to include new groups of users, new functionalities (use cases), and the integration with other IT systems in the future.

Having in view, an identified lack of communication (interoperability) between systems of entities providing health care and social care, we propose that consideration be given to the following initial architectural concept for the IT system:

\section{FIGURE 18 Proposed by WB IT system architecture}

Example of IT systems architecture

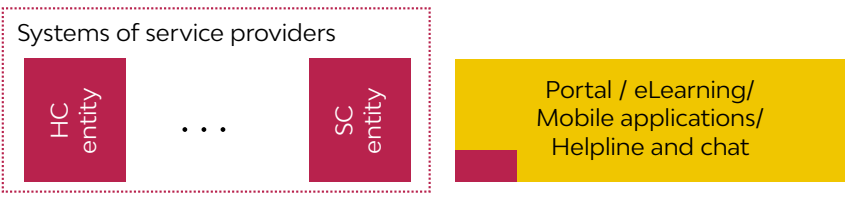

Terminal equipment (sensors, wearables, AR, robots, voice assistance)

\section{Platform for definition and implementation of care plans} (Care plans/Al)

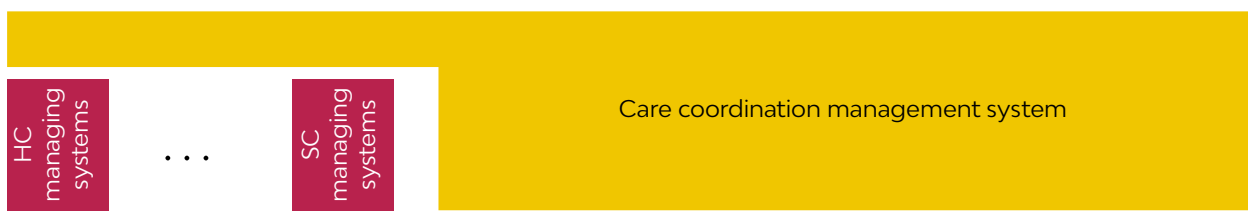

Existing IT systems New IT systems

In the above concept, the existing systems of service providers, which have been taken into account, should be supplemented with the necessary additional systems to carry out coordinated care. A detailed concept for implementing IT systems, including the phasing of implementation and the selection of technological solutions, should be prepared on the basis of detailed analyses conducted within an appropriate feasibility study.

The table below shows the entities responsible for the given IT system (administrator), and the users of the individual components of the IT system. 
TABLE 3 Recommended administrators and users of individual IT systems within coordinated care in Grudziądz

\begin{tabular}{|c|c|c|c|c|c|}
\hline & $\begin{array}{l}\text { Systems } \\
\text { of service } \\
\text { providers }\end{array}$ & $\begin{array}{l}\text { eLearning } \\
\text { portal / Mobile } \\
\text { applications / } \\
\text { Helpline and chat }\end{array}$ & Peripheral devices & $\begin{array}{l}\text { Platform for the } \\
\text { definition and } \\
\text { implementation } \\
\text { of care plans }\end{array}$ & $\begin{array}{l}\text { System for } \\
\text { managing the } \\
\text { coordination } \\
\text { of care }\end{array}$ \\
\hline Patients and caregivers & User & User & $\begin{array}{l}\text { Administrator / } \\
\text { User }\end{array}$ & User & \\
\hline $\begin{array}{l}\text { Entity/ies responsible for } \\
\text { the coordination system }\end{array}$ & & $\begin{array}{l}\text { Administrator / } \\
\text { Content provider }\end{array}$ & & Administrator & $\begin{array}{l}\text { Administrator / } \\
\text { User }\end{array}$ \\
\hline $\begin{array}{l}\text { Entities carrying out } \\
\text { health care, including: } \\
\text { - PHC/OSC clinics in } \\
\text { Grudziądz } \\
\text { - Regional hospital in } \\
\text { Grudziądz } \\
\text { - Rehabilitation }\end{array}$ & $\begin{array}{l}\text { Administrator / } \\
\text { User }\end{array}$ & Content provider & $\begin{array}{l}\text { Equipment } \\
\text { provider }^{*} \text { / User }\end{array}$ & User & User \\
\hline $\begin{array}{l}\text { Entities performing social } \\
\text { care, including: } \\
\text { - ROPS } \\
\text { - MOPR } \\
\text { - DPS }\end{array}$ & $\begin{array}{l}\text { Administrator / } \\
\text { User }\end{array}$ & Content provider & $\begin{array}{l}\text { Equipment } \\
\text { provider* / User }\end{array}$ & User & User \\
\hline NGOs & $\begin{array}{l}\text { Administrator / } \\
\text { User }\end{array}$ & Content providers & $\begin{array}{l}\text { Equipment } \\
\text { provider* / User }\end{array}$ & User & User \\
\hline
\end{tabular}

$\left({ }^{*}\right)$ It is acceptable that the provider of equipment for patients may be the entity that provides the care.

\section{TABLE 4 Main IT-system elements}

\begin{tabular}{|c|c|c|}
\hline Number & & \\
\hline 1. & $\begin{array}{l}\text { Platform for defining } \\
\text { and implementing } \\
\text { care plans }\end{array}$ & $\begin{array}{l}\text { 1. Care plans } \\
\text { - Creation/modification/monitoring of implementation } \\
\text { 2. Integration with the systems of the entities implementing care plans } \\
\text { 3. Analytical system/Al - prediction of events in care plan }\end{array}$ \\
\hline 2. & $\begin{array}{l}\text { System for managing } \\
\text { care coordination }\end{array}$ & $\begin{array}{l}\text { 1. Management of information on health needs and the state of health of the population } \\
\text { 2. Management of information related to care processes } \\
\text { 3. Resource allocation } \\
\text { 4. Evaluation and settlement of care services }\end{array}$ \\
\hline 3. & Front-end & $\begin{array}{l}\text { 1. Patient } \\
\text { - Helpline/chat } \\
\text { - Portal } \\
\text { - Mobile application } \\
\text { - Integration with peripheral devices } \\
\text { 2. Personnel performing care } \\
\text { - Interfaces of the systems of the entities providing care } \\
\text { - Mobile application } \\
\text { - Integration with peripheral devices that may be used in care processes } \\
\text { (for example, in the patient's home) } \\
\text { 3. Managers } \\
\text { - Portal } \\
\text { - Mobile application }\end{array}$ \\
\hline 4. & Peripheral devices & $\begin{array}{l}\text { - Mobile applications ( } 3^{\text {rd }} \text { party) } \\
\text { - Wearables } \\
\text { - Paging buttons } \\
\text { - Devices and sensors in patient's surroundings } \\
\text { - Robots, voice assistants }\end{array}$ \\
\hline 5. & $\begin{array}{l}\text { Systems of service } \\
\text { providers (health } \\
\text { care and social care } \\
\text { entities) }\end{array}$ & $\begin{array}{l}\text { 1. Integration with care plan's platform } \\
\text { 2. Integration with care coordination management system } \\
\text { 3. Introduction of new functionalities related to care performance } \\
\text { (for example, personnel support in patient's surroundings, telemedicine, telecare) }\end{array}$ \\
\hline
\end{tabular}


It is recommended that the IT system be implemented in two stages: first, at the local level, then, at the regional level.

\section{FIGURE 19 Proposed by WB framework schedule for implementation of IT systems}

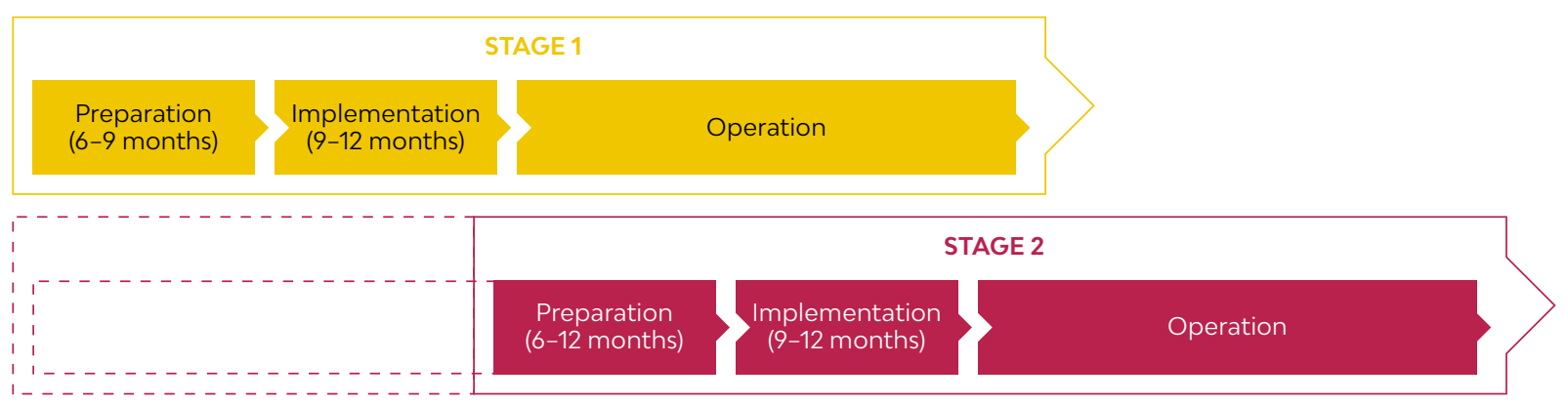

In the first stage of the framework schedule for the IT implementation, a local IT system should be introduced in Grudziądz that is supplied with data, either from existing systems, or that is entered directly by users. In the second stage, the following actions are recommended:

- Definition of the basic interoperability standards, in cooperation with national institutions (for example, CSIOZ - Center of Health Information Systems), and regional institutions (the Marshal Office of the Kujawsko-Pomorskie Region), as well as the supporting care coordination. It is recommended that consideration be given to the use of HL7 FHIR and IHE PCC/IHE XDW standards

- Implementation of an IT system (based on interoperability standards) enabling the exchange of the information (data) essential for care coordination. Consideration should be given to the incorporation of the care coordination system into the eHealth regional platform being built in the Kujawsko-Pomorskie Region

- Ensure the integration/interoperability of the IT systems in the entities engaged in coordinating care with the data exchange system (also based on interoperability standards)

\section{Recommendations related to the organization of the implementation of the IT systems}

1. Appointment of an IT implementation coordinator and implementation team (partial external support-outsourcing is possible)

2. Preparation of the basic implementation documents: an analysis of the feasibility of the IT systems that includes the specification of the IT systems, and the processes of their maintenance and development; as well as the documents essential in the process of ordering services

3. Prioritization of the functionalities that will be implemented in the individual stages, and the editions of appropriate IT systems. The recommended order of implementation is as follows:

- Basic/critical functionalities of the care plan's platform

- Basic functionalities of the communication with patients and their caregivers

- Basic functionalities of the management system

- The essential/critical scope of the integration between IT systems

4. Implementation of the procedures for evaluating the operation of the IT systems and updating the plans for their development

5. Providing the competencies and resources for the development of the IT systems

6. Providing training for the users of the IT systems 
Creation of the above IT system will allow to support the functioning of coordinated care through proper management of acquired data. The City Hall in Grudziądz or similar institution will be an administrator of the system and the city level for the population, however, individual patients/clients records will remain at the service provider level. The above-mentioned system should include the possibility of creating individual care plans for a senior patient. The process of creation of IT system for the electronic care plans has been proposed by us as a ready to use EU fische (see Appendix 5; the fische is available in Polish language version).

IT systems and tools development would need to be a subject of detailed feasibility studies. IT system feasibility study could generate cost from tens of thousands of zlotys to even hundreds, depending on the scope. 


\section{APPENDICES}

A detailed description of the FGI survey (available in English and Polish language version)

A list and description of the models currently implemented and used in other countries for the coordinated care of people over the age of 65 (available in English and Polish language version)

EU ready-to-use fische: Implementing the model of integrated care for elderly in Grudziądz (available in Polish language version)

EU ready-to-use fische: Organization of training for health care and social assistance personnel, as well as families and informal caregivers in the field of: available tools for comprehensive assessment of the state of health and needs of a patient above 65, elderly care provision, care plans implementation, care givers competences, as well as database of potential volunteer workers (carers) willing to take care of elderly, etc. (available in Polish language version)

EU ready-to-use fische: Building an IT tool enabling the creation of care plans for the elderly in Grudziądz, the so-called Care Plans (available in Polish language version)

EU ready-to-use fische: Adjustment of current health and social infrastructure in Grudziądz, as well as city transport, to the needs and abilities of seniors (available in Polish language version)

A set of materials on assessment of the health status of patients above 65 years, including the questionnaire of the Comprehensive Geriatric Assessment (available online in Polish language version:

https://worldbankgroup-my.sharepoint.com/personal/

akroljankowska_worldbank_org/_layouts/15/onedrive.

aspx?id=\%2Fpersonal\%2Fakroljankowska\%5Fworldbank\%5Forg\%2FDocuments

\%2FGrudziądz\%2Fmateria\%C5\%82y\%20na\%20szkolenie\%2014\%20czerwca) 


\section{NOTES}

1. Jakovljevic, Mihajlo Michael, Yael Netz, Sandra C. Buttigieg, Roza Adany, Ulrich Laaser, and Mirjana Varjacic. "Population aging and migration-history and UN forecasts in the EU-28 and its east and south near neighborhoodone century perspective 1950-2050." Globalization and health 14, no. 1 (2018): 30.

2. GUS (2014). Sytuacja demograficzna osób starszych i konsekwencje starzenia się ludności Polski w świetle prognozy na lata 2014-2050 (The demographic situation of elderly people and the consequences of the aging of the population of Poland in the light of projections for the years 2014-2050). Warsaw.

3. Hrynkiewicz, Józefina, Alina Potrykowska, Janusz Witkowski, and Rządowa Rada Ludnościowa. "Sytuacja demograficzna Polski jako wyzwanie dla polityki społecznej i gospodarczej. (Poland's demographic situation as a challenge for social and economic policy )" (2018).

4. GUS (2014). Demographic situation of the elderly and the consequences of aging of Poland's population in the light of projections for the years 2014-2050. Warsaw.

5. GUS (2017) Regional differences in aging of the population in Poland 1990-2015, with an outlook to 2040.

6. Grudziądz. City Website. Downloaded from: https:// Grudziądz.pl/; accessed 03/18/2019.

7. Grudziądz. City Website. Downloaded from: https:// Grudziądz.pl/; accessed 03/18/2019.

8. Day Center in Grudziądz. Downloaded from: https:// ddpmaksymilianGrudziądz.twoje-miasto.pl/, accessed 03/18/2019.

9. NHF. Directory of agreements. Downloaded from: http:// www.nfz.gov.pl/o-nfz/informator-o-zawartych-umowach/, accessed 03/26/2019.
10. Centrum Systemów Informacyjnych w Ochronie Zdrowia. Wyszukwianie podmiotów leczniczych (Center of Health Information Systems. Search for medical entities). Downloaded from: https://rpwdl.csioz.gov.pl/RPM/RegistryList; accessed 03/26/2019.

11. The data come from the Kujawsko-Pomorskie branch of the National Health Fund.

12. A single beneficiary may receive more than one benefit, in this case, both a cash benefit and a benefit in-kind.

13. Care services (ustugi opiekuńcze) are provided by social workers or care workers and cover various services of personal care and assistance in everyday activities.

14. The FGI was carried out by PBS Sp. z o.o..

15. McLafferty, Isabella. "Focus group interviews as a data collecting strategy." Journal of advanced nursing 48, no. 2 (2004): 187-194.

16. Interoperable-understood as compatible with other IT systems, supporting care, and using industry interoperability standards.

17. Béland, François, and Marcus J. Hollander. "Integrated models of care delivery for the frail elderly: international perspectives." Gaceta Sanitaria 25 (2011): 138-146.

18. NHS England. A guide to community-centered approaches for health and wellbeing. Downloaded from: https:// ec.europa.eu/regional_policy/sources/docgener/informat/2014/guidance_clld_local_actors.pdf \& https://assets. publishing.service.gov.uk/government/uploads/system/ uploads/attachment_data/file/768979/A_guide_to_community-centred_approaches_for_health_and_wellbeing_full_report_.pdf; accessed 06/18/2019

19. Stuck, Andreas E., and Steve Iliffe. "Comprehensive geriatric assessment for older adults." (2011): d6799, p.343. 